\title{
3D Seismic Interpretation and Well Log Analysis of the Marcellus Shale of Appalachian Basin at Taylor County, West Virginia
}

Lierong Zhu

Follow this and additional works at: https://researchrepository.wvu.edu/etd

\section{Recommended Citation}

Zhu, Lierong, "3D Seismic Interpretation and Well Log Analysis of the Marcellus Shale of Appalachian Basin at Taylor County, West Virginia" (2013). Graduate Theses, Dissertations, and Problem Reports. 7053.

https://researchrepository.wvu.edu/etd/7053

This Thesis is protected by copyright and/or related rights. It has been brought to you by the The Research Repository @WVU with permission from the rights-holder(s). You are free to use this Thesis in any way that is permitted by the copyright and related rights legislation that applies to your use. For other uses you must obtain permission from the rights-holder(s) directly, unless additional rights are indicated by a Creative Commons license in the record and/ or on the work itself. This Thesis has been accepted for inclusion in WVU Graduate Theses, Dissertations, and Problem Reports collection by an authorized administrator of The Research Repository @ WVU. For more information, please contact researchrepository@mail.wvu.edu. 


\title{
Using Tree-Ring Data to Analyze the Effects of Volcanic Eruptions on Climate in Inner Asia from 500 BCE to Present
}

\author{
Jennie Zhu \\ Thesis submitted \\ to the Eberly College of Arts and Sciences \\ At West Virginia University \\ in partial fulfillment of the requirements for the degree of \\ Master of Arts in \\ Department of Geography
}

\author{
Amy Hessl, Ph.D., Chair \\ Eungul Lee, Ph.D. \\ Jaime Toro, Ph.D. \\ Department of Geography
}

Morgantown, West Virginia

2016

Keywords: volcanic eruptions, Siberian pine, climate, dendrochronology, false rings, absent rings

Copyright 2016 Jennie Zhu 


\section{ABSTRACT \\ Using Tree-Ring Data to Analyze the Effects of Volcanic Eruptions on Climate in Inner Asia from 500 BCE to Present}

\section{Jennie Zhu}

Volcanic eruptions have influenced regional and global climate on annual, interannual, decadal, and multi-decadal time scales. However, past studies have largely focused on the response of global temperature to modern eruptions with the aid of satellite records. This approach limits the number of eruptions that can be studied and restricts our knowledge to relatively small events when compared to the volcanic history of the late Holocene. I used modern climate records to evaluate the effect of recent eruptions on Mongolian climate. I then extended my analysis to the last 2500 years by examining existing and new tree-ring data from Mongolia to understand how volcanic eruptions influence different climatic variables (temperature, moisture, and solar irradiance) in Inner Asia. This study, part of a larger research project on human ecology in Inner Asia, focuses on past volcanic eruptions (600 BCE to 2013 $\mathrm{CE})$ at three sites in north central Mongolia: Solongotyn Davaa $\left(48.3^{\circ} \mathrm{N}, 98.93^{\circ} \mathrm{E}\right)$, a temperature-limited site, Khorgo lava $\left(48.17^{\circ} \mathrm{N}, 99.87^{\circ} \mathrm{E}\right)$, and Urgaat lava $\left(46.40^{\circ} \mathrm{N}, 101.46^{\circ} \mathrm{E}\right)$, both moisture-limited sites. To test how modern eruptions (1959-2012) influenced temperature and precipitation regimes in Mongolia, I used the Grid Analysis and Display System to run composite analyses using Climatic Research Unit 3.21 temperature and 3.21 scPDSI data. Three eruptions were analyzed and both composite analyses suggest that, at each location, temperature and moisture variabilities are statistically insignificant during the year of the eruption. I then used superposed epoch analysis to evaluate how past eruptions affected regional climate by separating temperature, moisture, and solar irradiance variables. Again, the results fell within the $95 \%$ confidence limits for years zero to three, suggesting that these large eruptions do not affect temperature, moisture, and solar irradiance as much as once thought. Lastly, I looked at the tree-ring anatomy of individual samples to see if there was any anatomical evidence of an eruption event. Select eruption events are evidenced in tree-rings by the presence of narrow ring-width, false rings, and absent rings without any clear pattern as to why certain events affected tree growth at Khorgo lava and Urgaat lava. Chi-square tests comparing non-eruption years with eruption years show that the number of false rings and absent rings at Khorgo lava, and absent rings at Urgaat lava, is statistically significantly higher in the second year following the eruption, showing some effect on tree-ring growth but not necessarily tree-ring-width. The study calls into question the process of studying volcanic eruptions using tree-rings by showing that the atmosphere may be an intransitive cycle where the effects of volcanic eruptions can be variable and uncertain. 


\section{ACKNOWLEDGEMENTS}

This research was funded with grants by the National Geographic Society, National Science Foundation Coupled Natural and Human Systems (Award \#1210360), West Virginia University, and Columbia University. I would like to thank Dr. Amy Hessl for pushing me and never giving up on me even though I may have driven her insane a few times earning the name "El Niño". Thank you to the members of the Montane Forest Dynamics Lab especially Shawn Cockrell and Alex Dye for the support throughout my time at West Virginia University. Thank you to Cari Leland from Columbia University for spending the past summer with me in Mongolia collecting data and reminiscing about food and the NoVA life. 


\section{Table of Contents}

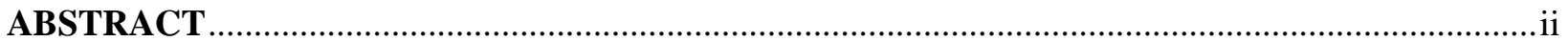

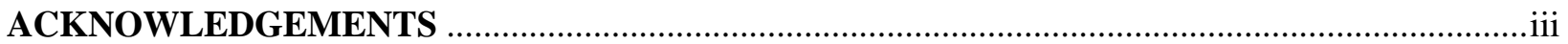

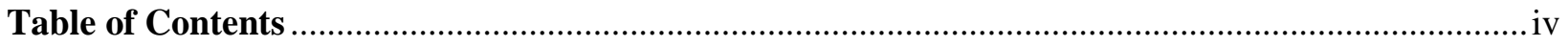

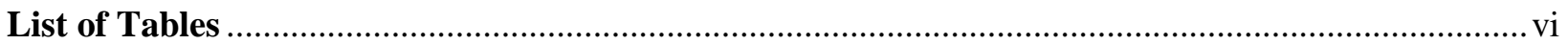

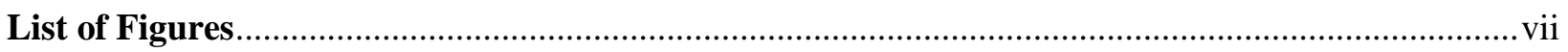

INTRODUCTION

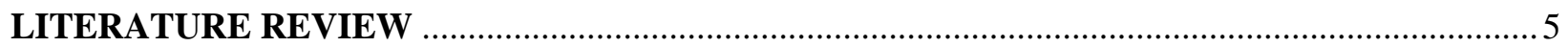

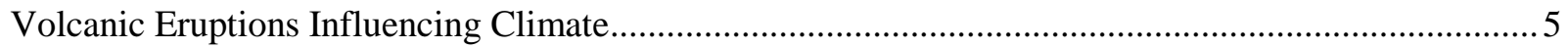

Using Tree-Rings to Study Past Volcanic Eruptions ......................................................................... 6

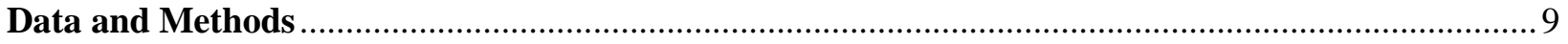

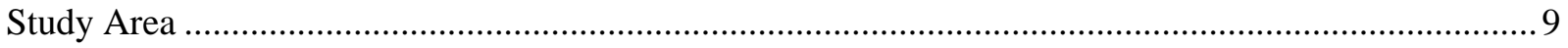

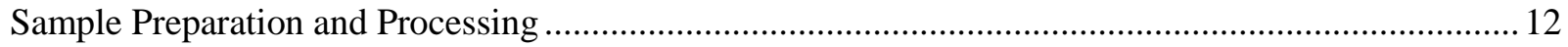

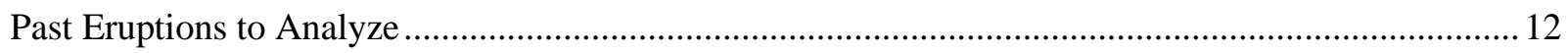

Modern Climatic Effects of Eruptions on Central Mongolia.............................................................. 18

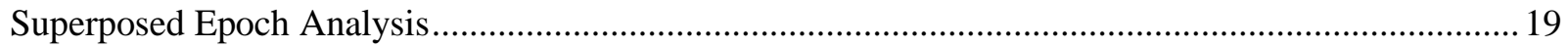

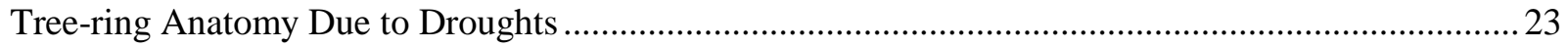

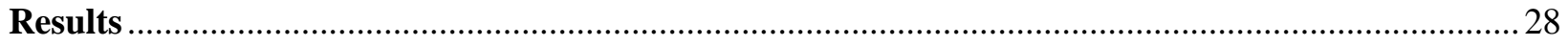

Volcanic Eruptions During the Instrumental Period in Mongolia ......................................................28

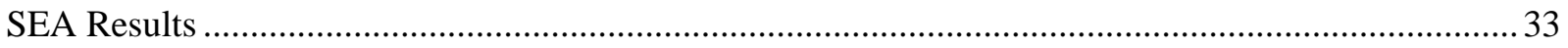

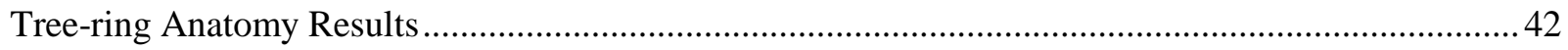




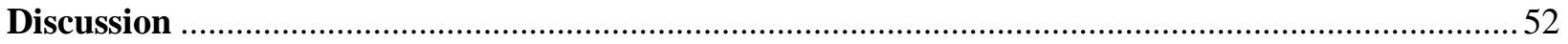

Instrumental Period Composite Analysis and SEA Analysis .........................................................52

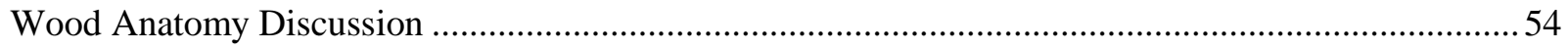

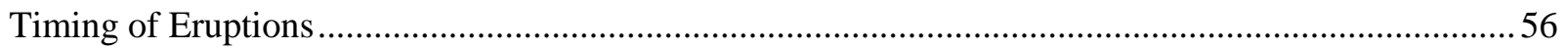

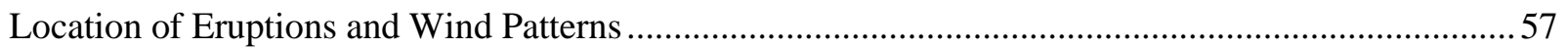

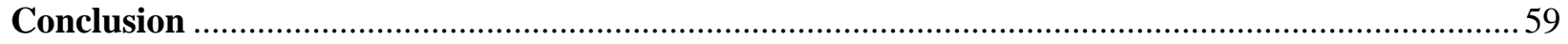

The Effects of Recent Eruptions on Climate of Central Mongolia .....................................................55

The Effects of Volcanic Eruptions on Tree Growth Over the Past 2,500 years ..................................59

How Eruptions Influence Climate in Central Mongolia ............................................................6 60

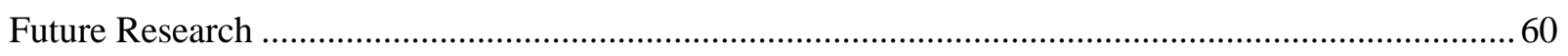

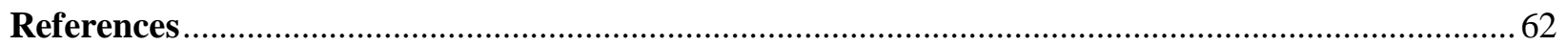




\section{List of Tables}

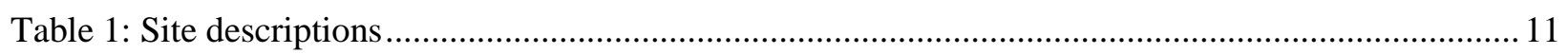

Table 2: Complete list of volcanic eruptions to be analyzed. …........................................................ 14

Table 3: Known timing of eruptions at Khorgo lava ...................................................................... 15

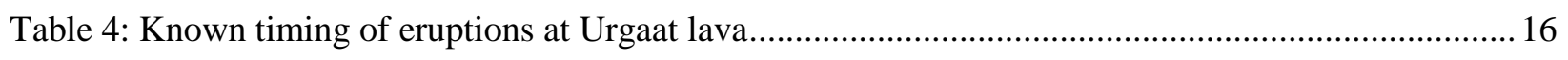

Table 5: Volcanic eruptions chosen for composite analysis during the modern period (1959-2012)......... 18

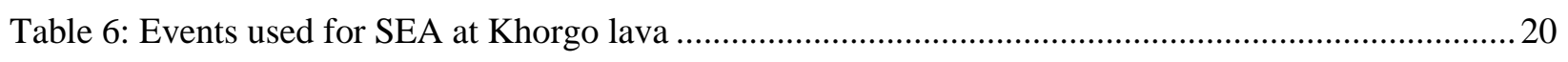

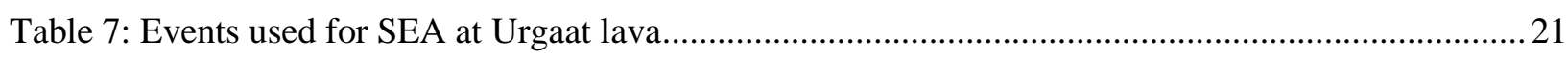

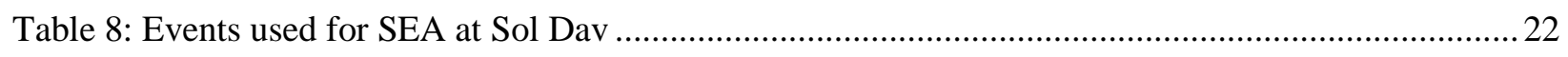

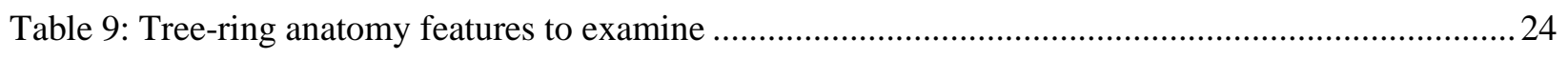

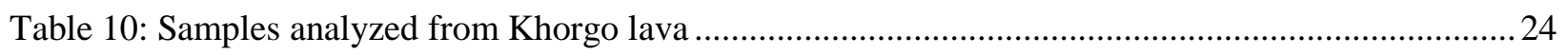

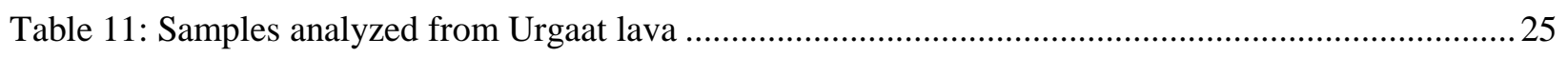

Table 12: Observed and total sample depth for Khorgo lava and Urgaat lava ......................................26

Table 13: Percent of observed samples showing false rings at Khorgo lava ......................................... 43

Table 14: Percent of observed samples showing false rings at Urgaat lava ..........................................4 44

Table 15: Percent of total samples in chronology showing absent rings at Khorgo lava......................... 45

Table 16: Percent of total samples in chronology showing absent rings at Urgaat lava......................... 46

Table 17: Chi-square results at Khorgo lava and Urgaat lava ..........................................................51 


\section{List of Figures}

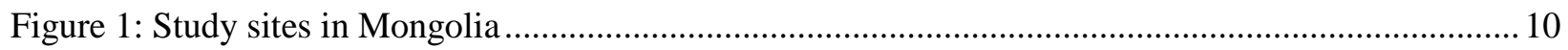

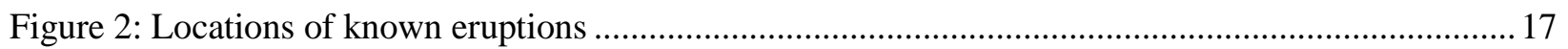

Figure 3: scPDSI composite difference using the 1963, 1982, and 1991 eruptions with a 54-year mean .. 29

Figure 4: scPDSI composite difference comparing the 1991 eruption with a 54 -year mean...................... 30

Figure 5: Temperature difference between the 1963, 1982, and 1991 eruptions with a 54-year mean .......31

Figure 6: Temperature difference between the 1991 eruption and 54-year average................................ 32

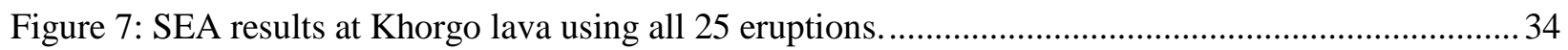

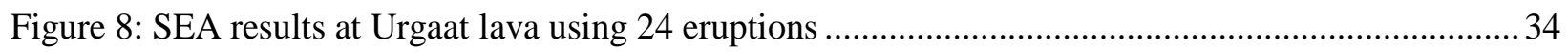

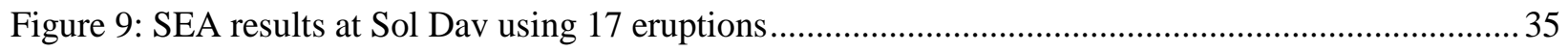

Figure 10: SEA performed at Khorgo lava using years in the reconstruction that has a sample depth of 10

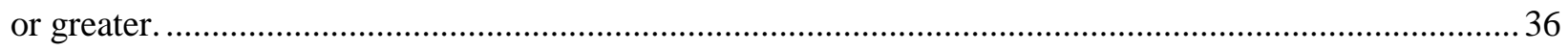

Figure 11: SEA performed at Urgaat lava using years in the reconstruction that has a sample depth of 10

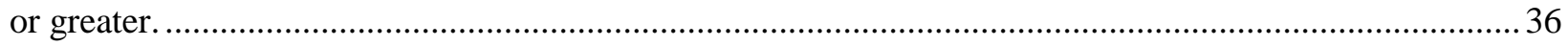

Figure 12: SEA performed at Sol Dav using years in the chronology that has a sample depth of 10 or

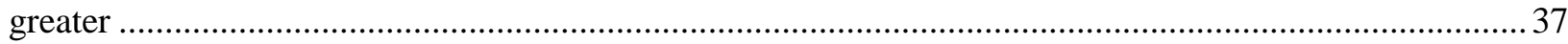

Figure 13: SEA using the 10 largest eruptions on the Sigl et al. (2015) table that also have at least 10

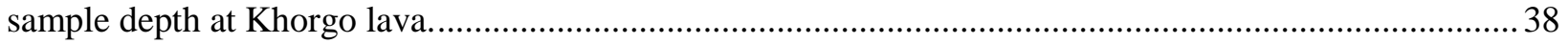

Figure 14: SEA using the 10 largest eruptions on the Sigl et al. (2015) table that also have at least 10

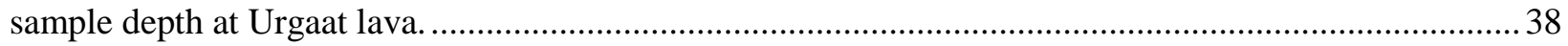

Figure 15: SEA using the 10 largest eruptions on the Sigl et al. (2015) table that also have at least 10 sample depth at Sol Dav.

Figure 16: SEA using the 5 largest eruptions on the Sigl et al. (2015) table that also have at least 10 sample depth at Khorgo lava. 
Figure 17: SEA using the 5 largest eruptions on the Sigl et al. (2015) table that also have at least 10 sample depth at Urgaat lava.

Figure 18: SEA using the 5 largest eruptions on the Sigl et al. (2015) table that also have at least 10 sample depth at Sol Dav.

Figure 19: Plotting reconstruction values against percent observed false rings, percent observed absent rings, and percent total absent rings at Khorgo lava

Figure 20: Plotting reconstruction values against percent observed false rings, percent observed absent rings, and percent total absent rings at Urgaat lava .50

Figure 21: SEA performed using Siberian larch at OZN (Davi et al. 2015).... .53 


\section{INTRODUCTION}

Volcanic eruptions have a strong influence on regional and global climate from interannual to century-long time scales (Stothers 2000, Salzer and Hughes 2006). Singular large tropical eruptions can produce global or hemispheric cooling for two to three years (Robock and Mao 1995, Kelly et al. 1996). In the Northern Hemisphere, the winter following a large tropical eruption is typically warmer due to cold season shifts in the Arctic Oscillation (Kelly and Jones 1996). Following eruptions of multiple large volcanoes, cooler temperatures have been experienced for 100-year periods (Crowley 2000, Robock 2000). For example, the massive Samalas eruption of 1258 CE (previously thought to be 1257) in Indonesia may have contributed to the onset of the Little Ice Age (LIA), a period spanning approximately 1400 to $1800 \mathrm{CE}$ when sea surface temperatures were $1^{\circ} \mathrm{C}$ cooler (Miller et al. 2012, Bradley and Jonest 1993, Keigwin 1996, Lavigne et al. 2013). These major eruptions and their associated climate forcing have had serious consequences for society. The $1258 \mathrm{CE}$ eruption, along with other eruptions such as Laki in $1783 \mathrm{CE}$ and an eruption of unknown location in $536 \mathrm{CE}$ and $540 \mathrm{CE}$, are both associated with cooler temperatures as well as poor harvests and famine (Stothers 1999, Sigl et al. 2015).

Studies of eruptions that occurred within the last 30 years have been aided by the availability of satellite records (Robock 2000). As a result, there is a large body of literature focusing on the $1991 \mathrm{CE}$

eruption of Mount Pinatubo in the Philippines including Kirchner et al. (1999), McCormick et al. (1995), and Minnis et al. (1993). The available satellite data, along with its tropical location and high intensity, provide insights into the effects of large eruptions on climate. Volcanic material from Mount Pinatubo was studied using modern instruments, therefore, we have a more complete understanding on how aerosols travel through the atmosphere, at what pace, and how eruptions affect the climate system, particularly Earth's radiative processes and stratospheric chemical processes (McCormick et al. 1995). However, volcanic eruptions of this magnitude, which have a global impact, are relatively rare events. There is an urgent need to study eruptions of varying magnitudes using a variety of data sources, including tree-rings, to improve the records on the effects of eruptions on past climate change. Due to the 
rarity of large modern eruptions, researchers have attempted to study several past eruptions of similar magnitude using model simulations (Oman et al. 2005, Mann et al. 2012). Oman et al. (2005) studied the Katmai eruptions of 1912 using the Goddard Institute for Space Studies ModelE GCM and stratospheric aerosol optical depth data showing a maximum cooling effect over Asia of about $1^{\circ} \mathrm{C}$ to $1.5^{\circ} \mathrm{C}$. Mann et al. (2012) modelled mean surface temperatures in the Northern Hemisphere using an energy-balance climate model and the US National Center for Atmospheric Research CSM 1.4 coupled ocean-atmosphere general circulation model that showed about a $2{ }^{\circ} \mathrm{C}$ decline in temperature following the 1258 eruption and then compared it to a tree-ring reconstruction that shows a decrease of only about $0.6^{\circ} \mathrm{C}$. There has been disagreement regarding the severity of temperature forcing (from $0.1{ }^{\circ} \mathrm{C}$ to up to $2.5^{\circ} \mathrm{C}$ surface temperature cooling) between model simulations and proxy records due to the inherent uncertainties contained in simulation models and proxy data. These uncertainties include weak correlation between instrumental temperatures and proxies, the detrending process and how proxy records can be affected by other climate and non-climatic influences, and incorrectly incorporating errors in the proxy data (IPCC 2013). There are also uncertainties in using the proxy themselves, including micro-site characteristics not detected while calibrating proxy against instrumental data and the amount of sulfate aerosols found in ice cores and if they're an accurate representation of the size of volcanic eruptions.

Tree-rings have long been used to study eruptions (Lawrence 1939, Lough and Fritts 1987, LaMarche and Hirschboeck 1984, Briffa et al. 1998, Salzer and Hughes 2007, Anchukaitis et al. 2012, D'Arrigo et al. 2013). Tree-rings are invaluable in this setting because they are annually resolved proxies of climate variability, are commonly found throughout the world, and their chronology dates as far back as 10,000 BCE. Radial tree growth is influenced by the most limiting environmental variable at a site. For example, trees growing at high elevations or high latitudes tend to be limited by temperature, thus, they act as a proxy for past temperature. As the result, temperature-sensitive trees have been used extensively to study temperature variability due to past volcanic eruptions (Briffa et al. 1998, D’Arrigo 2001, Anchukaitis 2012, Gennaretti et al. 2014). However, several studies suggest that major volcanic eruptions 
may influence irradiance and moisture availability, in addition to temperature (Wexler 1951, McCracken and Luther 1984, Handler 1984, Mass and Portman 1988, Dutton and Christy 1992, Roderick et al. 2001). By combining tree-ring data from a variety of sites that are either temperature or moisture-limited, it may be possible to attain a more complete understanding of the climatic effects of large eruptions.

I studied how past volcanic eruptions from $500 \mathrm{BCE}$ to $2013 \mathrm{CE}$ influenced Inner Asia climate using tree-ring chronologies of Siberian pine (Pinus sibirica) from three locations in north central Mongolia. The three sites are relatively near one another (within $300 \mathrm{~km}$ ), but are located in different topographic positions and thus are constrained by different growth-limiting factors. Khorgo lava (KLP) and Urgaat lava (ULP) are low elevation, moisture-limited sites, while Solongotyn Davaa (Sol Dav) is a high elevation temperature-limited site. D'Arrigo and others (2001) used the tree-ring record at Sol Dav to demonstrate that some tropical eruptions, such as the $536 \mathrm{CE}$ eruption, produced low temperatures in central Mongolia for one year (indicated by the presence of a frost ring), followed by a brief recovery in radial growth and then another decline in growth. Here I propose that tree-ring records from the three study sites may allow me to isolate different climatic effects of the eruption events beyond temperature.

This study will contribute to the scientific understanding of how historic volcanic eruptions influenced temperature, moisture, and irradiance regimes, by extending the available data and corresponding analysis back by 2,500 years and covering a unique range of geographic and climate variability, particularly on moisture-sensitive response at high latitudes. The objectives of this study are to:

1. Evaluate the effect of recent eruptions on the climate of central Mongolia using spatial fields of gridded temperature, moisture availability, and irradiance.

2. Expand the temporal window of volcanic effects on climate in central Mongolia by analyzing the effects of volcanic eruptions on tree growth over 2,500 years on three different sites in central Mongolia. 
I analyzed the different responses of moisture and temperature-sensitive trees to refine what we know about how eruptions alter climate in central Mongolia. I hypothesize that volcanic eruptions change key climate attributes (temperature, moisture availability, and solar irradiance), and influence the tree-ring data. If the dominant climatic effect is a decrease in temperature, this effect will be most apparent at temperature-limited sites such as Sol Dav. I expect to see a decrease in ring-width at Sol Dav and increase in ring-width at Khorgo lava and Urgaat lava. If the dominant climatic effect is an increase in moisture availability, then I expect to see an increase in ring-width and little changes in tree-ring anatomy in the samples from Khorgo lava and Urgaat lava. Lastly, if the dominant effect is an increase diffuse light, then I expect to see all sites experience an increase in tree productivity and thus an increase in ring-width. 


\section{LITERATURE REVIEW}

\section{Volcanic Eruptions Influencing Climate}

Volcanic eruptions influence climate by emitting sulfur dioxide which is then transformed into sulfate aerosols in the atmosphere (Devine et al. 1984, Zhao et al. 1995). These aerosols increase the optical thickness of the stratosphere, which decreases the amount of solar radiation reaching the earth's surface. These aerosols also absorb infrared energy radiated by the planet, reducing the average temperature of the troposphere (Hansen et al. 1978, Toon and Pollack 1980, Minnis et al. 1993, McMormick et al. 1995). There have been major eruptions during the last 2,500 years that have caused hemispheric and global cooling due to the amount of aerosols emitted (Kelly and Sear 1984). Since the advent of remote sensing, most of the recent research on the effects of volcanic activity on climate has focused on only a few eruptions, such as the 1991 eruption of Mount Pinatubo. In these studies, they found year 1992 to have an increase in diffuse radiation (and thus an increase in photosynthesis), summer cooling and winter warming patterns in January, and a mean tropospheric temperature $0.2^{\circ} \mathrm{C}$ below normal when compared to a base period of 1958 to 1991 (Gu et al. 2003, Kirchner et al. 1999, McCormick et al. 1995). Adjusted to take into the account the 1992 El Niño-Southern Oscillation (ENSO), there would have been a decrease of $-0.4^{\circ} \mathrm{C}$ in 1992 , which is a decrease of more than $0.7^{\circ} \mathrm{C}$ from 1991 (McCormick et al. 1995).

With only Mount Pinatubo as a modern reference for large eruptions, scientists have used a combination of model simulations and proxies to study older eruptions. However, there is disagreement between model simulations and reconstructions from proxies such as tree-rings. Simulations tend to overestimate surface temperature cooling resulting from major eruptions when compared to proxies (IPCC 2013). Model simulations show a decrease in mean surface temperature of approximately $1.0^{\circ} \mathrm{C}$ to $2.5^{\circ} \mathrm{C}$ for two to three years following large eruptions such as the $1258 \mathrm{CE}$ eruption (Oman et al. 2005, Mann et al. 2012). However, empirical reconstructions using tree-ring data with simulated climate models estimate only a $0.6^{\circ} \mathrm{C}$ to $2^{\circ} \mathrm{C}$ cooling for the $1258 \mathrm{CE}$ eruption in the Northern Hemisphere (Anchukaitis 
et al. 2012). Other empirical studies using volcanic dust effects and temperature records show a cooling of only a few tenths of a degree Celsius (Mass and Schneider 1977, Taylor et al. 1980, Self et al. 1981). This disagreement on the severity of cooling between models, tree-rings, and empirical studies is important because it shows the uncertainties present in relating model simulations, proxy records, and instrumental data, and a need to better understand these relationships.

In addition to temperature and precipitation effects, volcanic eruptions may also affect solar irradiance (Gu et al. 2003, Minnis et al. 1993, Dutton and Christy 1992). Solar radiation is observed to decrease by as much as 25 to $30 \%$ due to the backscattering of radiation by sulfate aerosols in the stratosphere, creating a global dimming effect (Dutton and Christy 1992). The solar radiation that is forward scattered to earth is enhanced diffuse radiation and somewhat compensates for the radiation that is backscattered into space (Robock 2000). Enhanced diffuse radiation can have a major effect on plant growth. Roderick et al. (2001) proposed that the enhanced diffuse radiation caused by eruptions increase photosynthesis. Gu et al. (2003) also studied the relationship between diffuse radiation and photosynthesis, concluding that the increase in diffuse radiation enhanced photosynthesis for two years following the Mount Pinatubo eruption. This concept is important to consider when using tree-rings as proxies because the enhanced diffuse radiation may help offset effects of cooler temperatures (Robock 2005).

\section{Using Tree-Rings to Study Past Volcanic Eruptions}

Tree-rings have been used to reconstruct and analyze past temperature (Briffa et al. 1998). In temperature-sensitive trees, the effects of volcanic eruptions on tree growth can be detected through the presence of narrow rings, frost rings (cellular growth differences due to freeze damage during the growth season), and rings with low maximum latewood density (LaMarche and Hirschboeck 1984, Salzer and Hughes 2007). Maximum latewood density is a measure based on the high density of cells formed at the end of each growing season, and is mostly limited by the cold temperature of late growing season (Parker and Jozsa 1973). However, studying this parameter is expensive and time consuming and not realistic for 
inclusion in this project. Frost rings may be present from eruptions and they typically show a more immediate response to temperature (D'Arrigo 1999). At Sol Dav, two out of the three samples that date to year $536 \mathrm{CE}$ show frost damage in the latewood of that year, signifying cooler temperatures during the year of the $536 \mathrm{CE}$ eruption. There were five frost rings out of 11 samples that corresponded to the 1258 CE eruption at Sol Dav. Other factors however, such as false rings, have been rarely studied, if at all. Sudden changes in the limiting factor during the growing season, such as moisture availability, can possibly produce false rings (Stokes and Smiley 1996).

Tree-ring reconstructions have been used to study temperature regimes in the years during and immediately following eruptions. Cooling caused by volcanic eruptions can appear for several years within temperature reconstructions based on ring width and frost ring data (D’Arrigo et al. 2013). However, along with the delay in surface cooling due to atmospheric circulation, there may also be a biological lag response in tree growth, shown as ring width (D'Arrigo et al. 2001). Narrow rings due to volcanic eruptions may be seen a few years after the occurrence of the eruption. Along with detecting individual volcanic eruptions, there are low-growth intervals that may be a result of several eruptions closely spaced in time (Salzer and Hughes 2007).

Temperature is commonly studied in bodies of literature involving the use of tree-rings to analyze the effects of volcanic eruptions on climate. Mann et al. (2012) used simulated data that predict a climate cooling of about $2^{\circ} \mathrm{C}$ during the modern period (1850-1999) and pre-instrumental period (1200-1980). He concluded that this effect is largely absent from tree-ring reconstructions of temperature (resulting in missing rings for the years coinciding with large eruptions such as the $1258 \mathrm{CE}$ Samalas eruption). However, it is rare for more than 5-10\% of samples from trees at northern latitude sites to have a missing ring per year (St. George et al. 2013). Anchukaitis et al. (2012) responded to Mann et al. highlighting problems with their tree-ring model including a lack of consideration for the amplitude and spatial pattern of volcanic forcing and climate responses and a lack of empirical evidence for misdating tree-ring chronologies. Their empirical models, along with other studies, showed cooling coinciding with volcanic 
eruptions, but with a one-year lag in narrow tree-rings and with only a cooling of approximately $0.5^{\circ} \mathrm{C}$ to $1^{\circ} \mathrm{C}$ (Anchukaitis et al. 2012, IPCC 2013, D’Arrigo et al. 2013, Gennaretti et al. 2014). Thus there is evidence that tree-ring chronologies are correctly dated and show surface temperature cooling, albeit less than the model projections.

There is less conclusive evidence regarding volcanic eruptions' influence on precipitation and irradiance in the tree-ring data. This is perhaps due to the low statistical significance found in connecting precipitation and eruptions, even while using modern instrumental and satellite data. Work performed by Wexler (1951), Mass and Portman (1988), Fischer et al. (2007), and Anchukaitis et al. (2010) show conflicting results on how eruptions influence precipitation. While it is hypothesized that eruptions may increase precipitation (Wexler 1951, McCracken and Luther 1984, Mass and Portman 1988), Anchukaitis et al. (2010) used tree-ring based drought reconstructions and the Superposed Epoch Analysis (SEA) to show that Inner Asia became drier following large eruptions. If the models by Anchukaitis et al. (2010) are accurate, then I expect to see drier conditions in Mongolia following large eruptions by analyzing moisture-sensitive tree-ring samples from Khorgo lava. Breitenmoser et al. (2012) analyzed the effects of volcanic eruptions on climate using a variety of time-series, including the temperature-sensitive chronologies (from Tornetrask, Central Europe, Yamal, Taimyr, Sol Dav, Indigirka, Puerto Café, and La Esperanza) and precipitation and drought chronologies (Prec. Qinghai, Drought Princeton, Drought El Malpais). They found that volcanic activities may mask the solar signal spatially and temporally, causing a decrease in temperature, but the results for precipitation and drought are less straightforward showing a negative volcanic effect in some areas but a positive effect in others. My research took this further by analyzing three sites one being temperature-sensitive and two being moisture-sensitive to research how volcanic eruptions influence temperature, precipitation, and irradiance regimes relative to one another. 


\section{Data and Methods}

Study Area

Mongolia is a landlocked country in inner Asia, with Russia on its northern border and China to the south, east, and west. The country has a land area of $1,564,116 \mathrm{~km}^{2}$ and human population estimated at 2,953,190 in 2014 (United Nations). The country is arid and semi-arid with pastoralism, mining, and agriculture as its main economic and cultural drivers (Johnson et al. 2006). Because of this, large natural events like volcanic eruptions and droughts can have major impacts on Mongolia's food supply, economy, and culture.

My first research site is Khorgo lava, which is located on a Holocene lava flow $\left(48.17^{\circ} \mathrm{N}\right.$, $99.87^{\circ} \mathrm{E}$ ) at an elevation of 2,060 $\mathrm{m}$ (Figure 1, Table 1). The site is moisture-stressed (Pederson et al. 2014). There are currently 191 samples dated in the master chronology that range from 668 BCE to 2013 CE. The second site is Urgaat lava $\left(46.70^{\circ} \mathrm{N}, 101.79^{\circ} \mathrm{E}\right)$ at an elevation of $2,016 \mathrm{~m}$. Moisture is also the limiting growth factor. Urgaat lava dates between 416 BCE to 2013 CE, with 105 processed and analyzed samples. The last site is Solongotyn Davaa (Sol Dav), a nearby high elevation site at $2,420 \mathrm{~m}\left(48.3^{\circ} \mathrm{N}\right.$, $98.93^{\circ} \mathrm{E}$ ) in the Tarvagatay Mountains (D'Arrigo et al. 2001). Temperature is the dominant control of tree growth due to the high elevation and mesic setting. Ninety total samples were collected from Sol Dav that date from $558 \mathrm{CE}$ to $1999 \mathrm{CE}$. Because the available chronology from Sol Dav does not date as far back as the moisture-limited sites, temperature information and analysis is limited to $558 \mathrm{CE}$ to $1999 \mathrm{CE}$. There has been some tree-ring anatomy analysis performed at Sol Dav from previous studies that go back to the 536 eruption (noted in the literature review) but the available chronology only dates to $558 \mathrm{CE}$ (D'Arrigo et al. 2001). These three sites act as proxies to reconstruct past temperature and moisture data that are used to analyze the effect of volcanic eruptions on local climate between 500 BCE and 2013 CE. For high elevation high latitude trees, narrow rings are typically produced in response to volcanic cooling (D’Arrigo et al. 1999). Less is known about climatic effects and tree response at low elevation moisturelimited sites. 


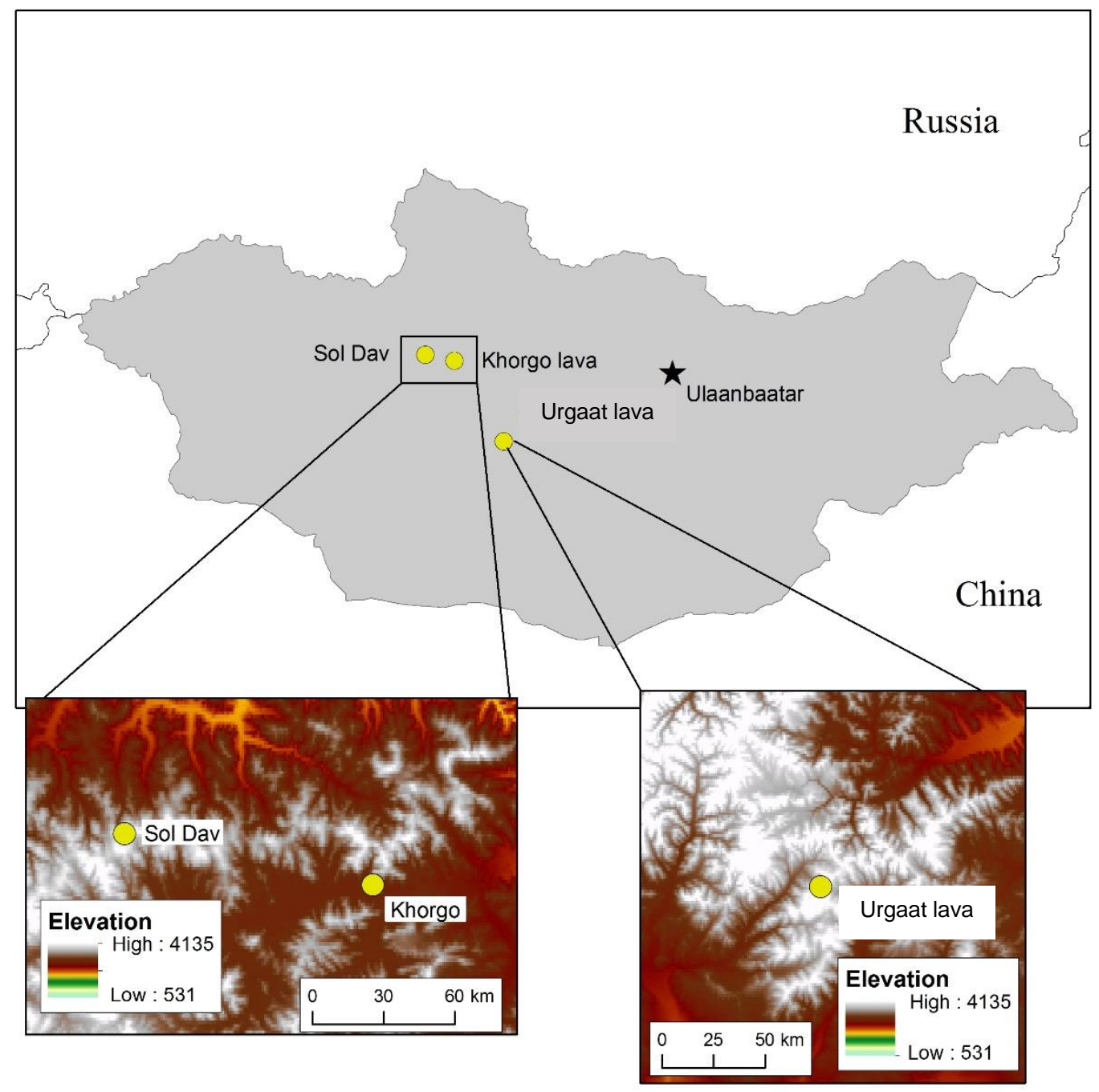

Figure 1: Study sites in Mongolia including elevation 
Table 1: Site descriptions

\begin{tabular}{llllll}
\hline Site & Elevation & $\begin{array}{l}\text { Limiting } \\
\text { Factor }\end{array}$ & Inner Ring & Outer Ring & \# of Samples \\
\hline Khorgo lava & $2060 \mathrm{~m}$ & Moisture & $668 \mathrm{BCE}$ & $2013 \mathrm{CE}$ & 191 \\
Urgaat lava & $2016 \mathrm{~m}$ & Moisture & $416 \mathrm{BCE}$ & $2013 \mathrm{CE}$ & 105 \\
Solongotyn Davaa & $2420 \mathrm{~m}$ & Temperature & $558 \mathrm{CE}$ & $1998 \mathrm{CE}$ & 90 \\
\hline
\end{tabular}




\section{Sample Preparation and Processing}

The samples from Khorgo lava and Urgaat lava were dried, mounted, and sanded according to standard dendrochronological techniques by several other technicians and myself (Stokes and Smiley 1996). Next, we crossdated and measured the ring widths of the samples to $0.01 \mathrm{~mm}$ precision using a measuring standard and microscope. The crossdating was checked using the computer program COFECHA to validate its accuracy against an existing master chronology (Holmes 1983). The existing master chronology for Khorgo lava has a sample depth of over 60 samples spanning $1140 \mathrm{CE}$ to $1770 \mathrm{CE}$ and a series intercorrelation of 0.71 . Urgaat lava has a series intercorrelation of 0.77 . The raw ring widths are standardized by Pederson et al. (2014) using a detrending method using the program ARSTAN to remove growth-related trends (Cook and Holmes 1986). Pederson et al. calibrated the standardized raw ring widths with soil moisture using a linear regression model relating June to September scPDSI to the ring width chronology from 1959 to 2009 and then validated the calibration using a split-period crossvalidation approach.

I attained the dataset for Sol Dav from the International Tree-Ring Data Bank (ITRDB) on the National Oceanic and Atmospheric Administration (NOAA) website. D'Arrigo et al. (2001) collected and processed the tree-ring samples from Sol Dav using basic dendrochronological techniques and then I standardized the data using ARSTAN to remove growth-related trends. However, Sol Dav cannot be used to generate calibrated and validated reconstructions due to limits of nearby meteorological station records (Davi et al. 2015). Thus, analyses of Sol Dav will use uncalibrated ring-width indices. Due to the high elevation and mesic setting, temperature is the dominant control of tree growth at Sol Dav (D'Arrigo et al. 2001).

Past Eruptions to Analyze

Sea surface temperatures, aerosol estimations, historical reports, radiation measurements, and ice cores have been used in previous studies to help create different indices of eruptions (Lamb 1970, Newhall and Self 1982, Robock and Free 1995). An ideal index conveys the radiative forcing associated 
with each explosive eruption, but indices of past eruptions are either incomplete spatially, temporally, or measure a single property (Briffa et al. 1998, Robock 2000). This research uses the years obtained from the Sigl et al. (2015) paper, a recent study that uses a combination of volcanic aerosol loadings from ice cores (from Greenland and Antarctica), tree-ring data from Central Europe, northern Siberia, and the United States, to obtain volcanic eruption events for the past 2,500 years (Tables 2-4, Figure 2)). The list contains and ranks the 25 largest eruptions during this time period based on total global aerosol forcing. The accuracy of these ice core chronologies were evaluated by comparing their volcanic aerosol loadings to an extensive database of the historical volcanic dust veil observations, ice core tephra evidence, and the $994 \mathrm{CE}$ event, and are accurate to within less than five years during the past 2,500 years (see more at Sigl et al. 2015). Just with all proxies, ice cores should be researched carefully and their uncertainties should be taken into consideration, such as how aerosols become deposited, by how much, and if all this is possibly by chance. This may come to explain if some eruptions are experienced elsewhere on the global context, or just near the poles where the ice cores are extracted.

In order to analyze these eruptions, I used the Climate Research Unit (CRU) high resolution monthly mean time series 3.21 global temperature data on a $0.5^{\circ}$ by $0.5^{\circ}$ grid that spans from 1901 to 2012 (Jones et al. 1999) and the CRU self-calibrating PDSI 3.21 global data on a $0.5^{\circ}$ by $0.5^{\circ}$ grid that spans from 1901 to 2012 (van der Schrier et al. 2013). The scPDSI is a calibrated index of PDSI by Palmer that calculates the moisture availability at any location derived from CRU 3.20 precipitation and evapotranspiration fields. It improves upon the PDSI in that the sensitivity of the index is based on the local climate. Tree-ring data for Sol Dav and Khorgo lava is provided by ITRDB. Siberian pine data at Sol Dav was originally collected by Jacoby et al. while the Siberian pine data at Khorgo lava was contributed by Hessl et al. The Urgaat lava Siberian pine data, although not yet available on the ITRDB, was also provided by Hessl et al. (2016). 
Table 2: Complete list of volcanic eruptions to be analyzed provided by Sigl et al. 2015. Edited to include only pertaining information

*Total global aerosol forcing was estimated by scaling the total sulfate flux from both polar ice sheets to the reconstructed total (that is, time integrated) aerosol forcing for Tambora 1815. For more detailed information, see Sigl et al. 2015.

\pm Unattributed volcanic events (UE) and tentative attributions for non-documented historic eruptions (?) are marked.

\begin{tabular}{|c|c|c|c|c|c|}
\hline Rank & Year & $\begin{array}{l}\text { Volc. } \mathrm{SO}_{4}{ }^{2-} \\
\text { Greenland } \\
\left(\mathrm{kg} \mathrm{km}^{-2}\right)\end{array}$ & $\begin{array}{l}\text { Volc. } \mathrm{SO}_{4}^{2-} \\
\text { Antarctica } \\
\left(\mathrm{kg} \mathrm{km}^{-2}\right)\end{array}$ & $\begin{array}{l}\text { Global } \\
\text { forcing* } \\
\left(\mathbf{W} \mathbf{m}^{-2}\right)\end{array}$ & Volcano $\pm /$ Region \\
\hline 1 & -426 & 99.8 & 78.2 & -35.6 & UE \\
\hline 2 & 1258 & 90.4 & 73.4 & -32.8 & Samalas/Indonesia \\
\hline 3 & -44 & 100.6 & 15.4 & -23.2 & Chiltepe?/Nicaragua \\
\hline 4 & 1458 & 39 & 63.6 & -20.5 & Kuwae/Vanuatu \\
\hline 5 & 540 & 61.2 & 34.4 & -19.1 & Ilopango?/El Salvador \\
\hline 6 & 1815 & 39.7 & 45.8 & -17.1 & Tambora/Indonesia \\
\hline 7 & 1230 & 56.4 & 23.1 & -15.9 & UE \\
\hline 8 & 1783 & 135.8 & & -15.5 & Laki/Iceland \\
\hline 9 & 682 & 38.4 & 38.7 & -15.4 & Pago?/New Britain \\
\hline 10 & 574 & 38.3 & 34.1 & -14.5 & Rabaul?/New Britain \\
\hline 11 & 266 & 61 & 11.3 & -14.5 & UE \\
\hline 12 & 1809 & 34.6 & 25.4 & -12 & UE \\
\hline 13 & 1108 & 48.3 & 11.6 & -12 & UE \\
\hline 14 & 1641 & 44.2 & 14.9 & -11.8 & Parker/Philippines \\
\hline 15 & 1601 & 39.2 & 18.7 & -11.6 & Huaynaputina/Peru \\
\hline 16 & 169 & 39.1 & 18.4 & -11.5 & UE \\
\hline 17 & 1171 & 37 & 19.5 & -11.3 & UE \\
\hline 18 & 536 & 99 & & -11.3 & UE \\
\hline 19 & 1695 & 28.6 & 22.5 & -10.2 & UE \\
\hline 20 & 939 & 88.7 & & -10.1 & Eldgja/Iceland \\
\hline 21 & 1286 & 27.6 & 20.8 & -9.7 & Quilotoa?/Ecuador \\
\hline 22 & 433 & 20.6 & 27.2 & -9.6 & UE \\
\hline 23 & 87 & 83.1 & & -9.5 & UE \\
\hline 24 & 1345 & 27.9 & 19.1 & -9.4 & El Chichon?/Mexico \\
\hline 25 & 626 & 72.2 & & -8.2 & UE \\
\hline
\end{tabular}


Table 3: Known timing of eruptions at Khorgo lava along with which year the narrow ring-width was recorded in the chronology, and location of eruptions

\begin{tabular}{|c|c|c|c|c|c|c|c|}
\hline \multicolumn{8}{|c|}{ Khorgo Lava Pine - Timing of Eruption } \\
\hline $\begin{array}{c}\text { Eruption } \\
\text { Event }\end{array}$ & $\begin{array}{c}\text { Narrow } \\
\text { Eruption } \\
\text { Year }\end{array}$ & $\begin{array}{c}\text { Narrow } \\
\text { Year } \\
\text { After } \\
\text { Eruption }\end{array}$ & $\begin{array}{c}\text { Before } \\
\text { Growing } \\
\text { Season? }\end{array}$ & $\begin{array}{c}\text { After } \\
\text { Growing } \\
\text { Season? }\end{array}$ & $\begin{array}{c}\text { Date of } \\
\text { Eruption }\end{array}$ & Source & Location \\
\hline-426 & $\mathrm{x}$ & & - & - & - & - & - \\
\hline-44 & $\mathrm{x}$ & & $\mathrm{x}$ & & March & Stothers 1999 & Nicaragua \\
\hline 87 & & $\mathrm{x}$ & - & - & - & - & - \\
\hline 169 & $\mathrm{x}$ & & - & - & - & - & - \\
\hline 266 & & $\mathrm{x}$ & - & - & - & - & _ \\
\hline 433 & & $\mathrm{x}$ & - & - & - & - & ـ \\
\hline 536 & $\mathrm{x}$ & & $\mathrm{x}$ & & March & Stothers 1999 & _ \\
\hline 540 & & $\mathrm{x}$ & - & - & - & - & $\begin{array}{c}\text { El } \\
\text { Salvador }\end{array}$ \\
\hline 574 & $\mathrm{x}$ & & - & - & - & - & $\begin{array}{l}\text { New } \\
\text { Britain }\end{array}$ \\
\hline 626 & & $\mathrm{x}$ & & $\mathrm{x}$ & October & Stothers 1999 & _ \\
\hline 682 & $\mathrm{x}$ & & - & - & - & - & $\begin{array}{l}\text { New } \\
\text { Britain }\end{array}$ \\
\hline 939 & $\mathrm{x}$ & & $\mathrm{x}$ & & Summer & Stothers 1999 & Iceland \\
\hline 1108 & & $\mathrm{x}$ & - & - & - & - & ـ \\
\hline 1171 & $\mathrm{x}$ & & - & - & - & - & _ \\
\hline 1230 & & $\mathrm{x}$ & - & - & - & - & ـ \\
\hline 1258 & & $\mathrm{x}$ & $\mathrm{x}$ & & January & Stothers 1999 & Indonesia \\
\hline 1286 & $\mathrm{x}$ & & - & - & - & - & Ecuador \\
\hline 1345 & & $\mathrm{x}$ & - & - & - & - & Mexico \\
\hline 1458 & & $\mathrm{x}$ & - & - & - & - & Vanuatu \\
\hline 1601 & $\mathrm{x}$ & & $\mathrm{x}$ & & $\begin{array}{c}\text { February } \\
1600\end{array}$ & $\begin{array}{c}\text { Thouret et al. } \\
1999\end{array}$ & Peru \\
\hline 1641 & $\mathrm{x}$ & & $\mathrm{x}$ & & January? & & Philippines \\
\hline 1695 & & $\mathrm{x}$ & - & - & - & - & _ \\
\hline 1783 & $\mathrm{x}$ & & $\mathrm{x}$ & & June & Stothers 1999 & Iceland \\
\hline 1809 & $\mathrm{x}$ & & $\mathrm{x}$ & & $\begin{array}{c}\text { December } \\
1808 ?\end{array}$ & $\begin{array}{c}\text { Guevara- } \\
\text { Murua et al. } \\
2014 \\
\end{array}$ & - \\
\hline 1815 & $\mathrm{x}$ & & $\mathrm{x}$ & & April & Stothers 1984 & Indonesia \\
\hline
\end{tabular}


Table 4: Known timing of eruptions at Urgaat lava along with which year the narrow ring-width was recorded in the chronology, and location of eruptions

\begin{tabular}{|c|c|c|c|c|c|c|c|}
\hline \multicolumn{8}{|c|}{ Urgaat Lava Pine - Timing of Eruption } \\
\hline $\begin{array}{c}\text { Eruption } \\
\text { Event }\end{array}$ & $\begin{array}{c}\text { Narrow } \\
\text { Eruption } \\
\text { Year }\end{array}$ & $\begin{array}{c}\text { Narrow } \\
\text { Year } \\
\text { After } \\
\text { Eruption }\end{array}$ & $\begin{array}{c}\text { Before } \\
\text { Growing } \\
\text { Season? }\end{array}$ & $\begin{array}{c}\text { After } \\
\text { Growing } \\
\text { Season? }\end{array}$ & $\begin{array}{c}\text { Date of } \\
\text { Eruption }\end{array}$ & Source & Location \\
\hline-426 & NA & NA & NA & NA & - & - & - \\
\hline-44 & & $\mathrm{x}$ & $\mathrm{x}$ & & March & $\begin{array}{c}\text { Stothers } \\
1999\end{array}$ & Nicaragua \\
\hline 87 & $\mathrm{x}$ & & - & - & - & - & - \\
\hline 169 & & $\mathrm{x}$ & - & - & - & - & - \\
\hline 266 & $\mathrm{x}$ & & - & - & - & - & - \\
\hline 433 & $\mathrm{x}$ & & - & - & - & - & - \\
\hline 536 & $\mathrm{x}$ & & $\mathrm{x}$ & & March & $\begin{array}{c}\text { Stothers } \\
1999\end{array}$ & - \\
\hline 540 & & $\mathrm{x}$ & - & - & - & - & $\begin{array}{c}\text { El } \\
\text { Salvador }\end{array}$ \\
\hline 574 & $\mathrm{x}$ & & - & - & - & - & $\begin{array}{c}\text { New } \\
\text { Britain }\end{array}$ \\
\hline 626 & & $\mathrm{x}$ & & $\mathrm{x}$ & October & $\begin{array}{c}\text { Stothers } \\
1999\end{array}$ & - \\
\hline 682 & & $\mathrm{x}$ & - & - & - & - & $\begin{array}{c}\text { New } \\
\text { Britain }\end{array}$ \\
\hline 939 & $\mathrm{x}$ & & $\mathrm{x}$ & & Summer & $\begin{array}{c}\text { Stothers } \\
1999\end{array}$ & Iceland \\
\hline 1108 & & $\mathrm{x}$ & - & - & - & - & - \\
\hline 1171 & $\mathrm{x}$ & & - & - & - & - & - \\
\hline 1230 & & $\mathrm{x}$ & - & - & - & - & - \\
\hline 1258 & $\mathrm{x}$ & & $\mathrm{x}$ & & January & $\begin{array}{c}\text { Stothers } \\
1999 \\
\end{array}$ & Indonesia \\
\hline 1286 & $\mathrm{x}$ & & - & - & - & - & Ecuador \\
\hline 1345 & & $\mathrm{x}$ & - & - & - & - & Mexico \\
\hline 1458 & & $\mathrm{x}$ & - & - & - & - & Vanuatu \\
\hline 1601 & $\mathrm{x}$ & & $\mathrm{x}$ & & $\begin{array}{c}\text { February } \\
1600\end{array}$ & $\begin{array}{c}\text { Thouret } \\
\text { et al. } \\
1999 \\
\end{array}$ & Peru \\
\hline 1641 & & $\mathrm{x}$ & $\mathrm{x}$ & & January? & & Philippines \\
\hline 1695 & & $\mathrm{x}$ & - & - & - & - & - \\
\hline 1783 & & $\mathrm{x}$ & $\mathrm{x}$ & & June & $\begin{array}{c}\text { Stothers } \\
1999\end{array}$ & Iceland \\
\hline 1809 & $\mathrm{x}$ & & $\mathrm{x}$ & & $\begin{array}{c}\text { December } \\
1808 ?\end{array}$ & $\begin{array}{l}\text { Guevara- } \\
\text { Murua et } \\
\text { al. } 2014\end{array}$ & - \\
\hline 1815 & $\mathrm{x}$ & & $\mathrm{x}$ & & April & $\begin{array}{c}\text { Stothers } \\
1984\end{array}$ & Indonesia \\
\hline
\end{tabular}




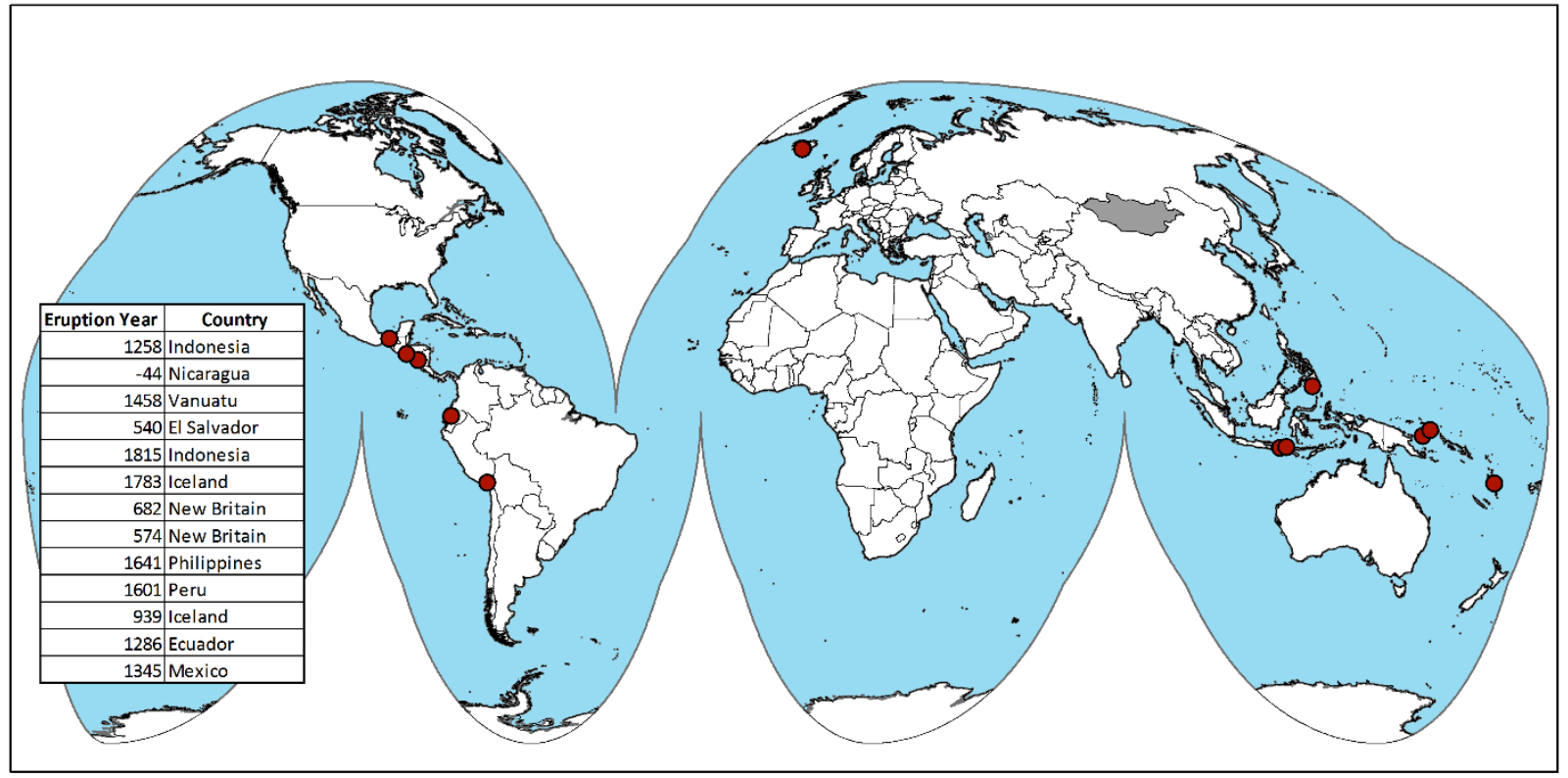

Figure 2: Locations of eruptions at known locations from Sigl et al. (2015) table 
Modern Climatic Effects of Eruptions on Central Mongolia

I performed a preliminary analysis to test the influence of eruptions on temperature and moisture availability regimes in Mongolia during the modern instrumental period. The goal was to see if there were any climatic effects in Mongolia using available instrumental data. I used the Grid Analysis and Display System (GrADS; Doty 1995) to run composite analyses using CRU 3.21 temperature and CRU scPDSI 3.21 data. I examined large (Volcanic Explosivity Index (VEI) of 5 or greater) tropical volcanic eruptions between 1959 and 2012 (Table 5).

Table 5: Volcanic eruptions chosen for composite analysis during the modern period (1959-2012)

\begin{tabular}{lllc}
\hline $\begin{array}{l}\text { Volcanic Event } \\
\text { Year }\end{array}$ & Name & Location & VEI \\
\hline 1963 & Mount Agung & Bali, Indonesia & 5 \\
1982 & El Chichón & Francisco León, Mexico & 5 \\
1991 & Mount Pinatubo & Luzon, Philippines & 6 \\
\hline
\end{tabular}


Because the three eruptions happened before my sites' general growing season (growing season of June, July, August, September), I analyzed only the year of the eruption because it would have impacted the current year's climatic variable. The composite, with $n$ being year of eruption, is

$$
\text { composite }=\left(\frac{n 1+n 2+n 3}{3}\right)-54 \text { year average }
$$

for both CRU temperature and CRU scPDSI analyses. I repeated the same process using only the 1991 Mount Pinatubo eruption since it is the largest eruption that has occurred during the instrumental period and might show a less muted effect. Significance levels $(\mathrm{p} \leq 0.05)$ were calculated using a t-test on GrADS and were contoured in composite maps for the three eruptions. The composite maps including only Mount Pinatubo did not have significance levels calculated because the sample size is only one.

\section{Superposed Epoch Analysis}

Superposed epoch analysis (SEA) is commonly used in studies involving the effects of volcanic eruptions on climate (Kelly and Sear 1984). The objective of SEA is to help clarify volcanic signals not common to individual events (noise) by identifying weak signals present in noisy data from the effects of a particular sequence of events (Taylor et al. 1980). For this project, I conducted SEA for each site to attempt to separate moisture, temperature, and irradiance influences.

To conduct SEA, first I selected event dates from the volcanic eruption time series (Table 2) (Sigl et al. 2015). I averaged the variables of these dates (i.e. reconstructed scPDSI data from tree-rings) in the statistical program $\mathrm{R}$ to produce pre- and post- volcanic signals over a nine-year window centered on the eruption year (year 0). The superposition clarifies the volcanic signals by averaging out features not common to individual events, which are believed to be caused by non-volcanic factors (Kelly and Sear 1984). I derived statistical significance from 10,000 Monte Carlo simulations of windows of the same length selected at random from the entire time series of the climate variable (Haurwitz and Brier 1981, Mooney and Duval 1993). 
I ran SEA four times for each three sites: 1) all available eruption years, 2) eruption years with corresponding sample depth of 10 or greater, 3) top 10 largest eruptions according to the Sigl et al. paper (that also have a sample depth of 10 or greater), and 4) top five largest eruption with a sample depth of 10 or greater (Tables 6 - 8). For the first run, all 25 eruptions are used when performing SEA at Khorgo lava. However, only 24 eruptions are used for Urgaat lava and 17 eruptions at Sol Dav due to shorter chronologies.

Table 6: Events used for SEA at Khorgo lava

\begin{tabular}{llll}
\multicolumn{5}{l}{ Khorgo Lava Pine - Eruption Event Years Used for SEA Analysis } \\
\hline All Eruption & $\begin{array}{l}\text { At Least 10 } \\
\text { Events }\end{array}$ & $\begin{array}{l}\text { Top 10 Largest } \\
\text { Sample Depth }\end{array}$ & $\begin{array}{l}\text { Top 5 Largest } \\
\text { Eruption Events }\end{array}$ \\
Eruption Events \\
\hline-426 & -44 & -44 & -44 \\
-44 & 87 & 266 & 540 \\
87 & 169 & 540 & 1258 \\
169 & 266 & 574 & 1458 \\
266 & 433 & 682 & 1815 \\
433 & 536 & 1230 & \\
536 & 540 & 1258 & \\
540 & 574 & 1458 & \\
574 & 626 & 1783 & \\
626 & 682 & 1815 & \\
682 & 939 & & \\
939 & 1108 & & \\
1108 & 1171 & & \\
1171 & 1230 & & \\
1230 & 1258 & & \\
1258 & 1286 & & \\
1286 & 1345 & & \\
1345 & 1458 & & \\
1458 & 1601 & & \\
1601 & 1641 & & \\
1641 & 1695 & & \\
1695 & 1783 & & \\
1783 & 1809 & & \\
1809 & 1815 & & \\
1815 & & & \\
25 & 24 & & \\
\hline
\end{tabular}


Table 7: Events used for SEA at Urgaat lava

Urgaat Lava Pine - Eruption Event Years Used for SEA Analysis

\begin{tabular}{|c|c|c|c|}
\hline $\begin{array}{l}\text { All Eruption } \\
\text { Events }\end{array}$ & $\begin{array}{l}\text { At Least 10 } \\
\text { Sample Depth }\end{array}$ & $\begin{array}{l}\text { Top } 10 \text { Largest } \\
\text { Eruption Events }\end{array}$ & $\begin{array}{l}\text { Top } 5 \text { Largest } \\
\text { Eruption Events }\end{array}$ \\
\hline-44 & 536 & 266 & 540 \\
\hline 87 & 540 & 540 & 1230 \\
\hline 169 & 574 & 574 & 1258 \\
\hline 266 & 626 & 682 & 1458 \\
\hline 433 & 682 & 1230 & 1815 \\
\hline 536 & 939 & 1258 & \\
\hline 540 & 1108 & 1458 & \\
\hline 574 & 1171 & 1783 & \\
\hline 626 & 1230 & 1809 & \\
\hline 682 & 1258 & 1815 & \\
\hline 939 & 1286 & & \\
\hline 1108 & 1345 & & \\
\hline 1171 & 1458 & & \\
\hline 1230 & 1601 & & \\
\hline 1258 & 1641 & & \\
\hline 1286 & 1695 & & \\
\hline 1345 & 1783 & & \\
\hline 1458 & 1809 & & \\
\hline 1601 & 1815 & & \\
\hline \multicolumn{4}{|l|}{1641} \\
\hline \multicolumn{4}{|l|}{1695} \\
\hline \multicolumn{4}{|l|}{1783} \\
\hline \multicolumn{4}{|l|}{1809} \\
\hline \multicolumn{4}{|l|}{1815} \\
\hline 24 & 19 & 10 & 5 \\
\hline
\end{tabular}

Total Events: 24 
Table 8: Events used for SEA at Sol Dav

Sol Dav - Eruption Event Years Used for SEA Analysis

\begin{tabular}{llll}
\hline $\begin{array}{lll}\text { All Eruption } \\
\text { Events }\end{array}$ & $\begin{array}{l}\text { At Least 10 } \\
\text { Sample Depth }\end{array}$ & $\begin{array}{l}\text { Top 10 Largest } \\
\text { Eruption Events }\end{array}$ & $\begin{array}{l}\text { Top 5 Largest } \\
\text { Eruption Events }\end{array}$ \\
\hline 574 & 939 & 574 & 1230 \\
626 & 1108 & 682 & 1258 \\
682 & 1171 & 1108 & 1458 \\
939 & 1230 & 1230 & 1783 \\
1108 & 1258 & 1258 & 1815 \\
1171 & 1286 & 1458 & \\
1230 & 1345 & 1641 & \\
1258 & 1458 & 1783 & \\
1286 & 1601 & 1809 & \\
1345 & 1641 & 1815 & \\
1458 & 1695 & & 5 \\
1601 & 1783 & & \\
1641 & 1809 & & \\
1695 & 1815 & & \\
1783 & & 10 & \\
1809 & & & \\
1815 & 14 & & \\
Total Events: & & & \\
\hline
\end{tabular}




\section{Tree-ring Anatomy Due to Droughts}

In addition to the SEA statistical analysis, I looked for anatomical evidence (ring width, frost rings, false rings, locally absent rings, and completely absent rings) (Table 9) of volcanic eruptions from the Khorgo lava and Urgaat lava tree samples (Tables 10 - 11). Like SEA, I examined 9-year windows centered on each eruption year. Observed and total sample depths are listed under Table 12. Observed samples are what I found while examining cross-sections from the list of samples under Table 10 and Table 11 (for false rings and absent rings) while the total sample depth (only available for absent rings) includes values from the entire chronology. Sol Dav is excluded from this analysis since we do not have the cross-sections.

Each anatomical feature of a tree-ring is important in studying if tree-growth is affected by large events such as volcanic eruptions. Ring width, or the size of each ring measured to $0.01 \mathrm{~mm}$ precision, is important because it shows the general growth pattern of a tree and if there were any anomalies (especially large or small rings) that may have been caused by the limiting factor during that year of the growing season. Frost rings are annual growth increments that have cellular irregularities caused by freeze damage during the growing season that signify cold conditions related to volcanic and other large events that cause colder than average temperatures (D'Arrigo et al. 2001, LaMarche and Hirschboeck 1984). False rings, or "double rings", are where a dark-colored latewood band appears in the light-colored earlywood of the ring. Frequently the last-formed latewood of a false ring is not clearly delineated because it gradually blends in with the earlywood on either side (Stokes and Smiley 1996). This suggests that there may have been an onset of a decrease in limiting factor (cooler temperatures or drier growing season) before the end of the growing season. Locally absent rings and completely absent rings are similar. The locally absent ring is the absence of an annual ring from some portion of the sample. A completely absent ring is when the ring is not visible at any location of the cross-section. Both these features are caused by a decrease in the limiting factor (such as a decrease in temperature or a decrease in moisture availability) at each location. 
Table 9: Tree-ring anatomy features to examine

\begin{tabular}{l} 
Ring Anatomy Feature \\
\hline Ring-width \\
Frost Ring \\
False Ring \\
Locally Absent Ring \\
Completely Absent Ring \\
\hline
\end{tabular}

Table 10: Samples analyzed from Khorgo lava, including the inside ring year, outside ring year, and total number of rings

\begin{tabular}{lrrr}
\multicolumn{4}{l}{ Khorgo Lava Pine } \\
Sample ID & Inside & Outside & Rings \\
\hline KLP3023x & 562 & 1472 & 911 \\
KLP3036x & 1434 & 1840 & 407 \\
KLP3040x & 984 & 1399 & 416 \\
KLP3067x & 497 & 1090 & 594 \\
KLP3079x & 105 & 736 & 632 \\
KLP3087x & 31 & 854 & 824 \\
KLP3110x & 345 & 878 & 534 \\
KLP3118 & 1130 & 1456 & 327 \\
KLP3156x & 155 & 755 & 601 \\
KLP4061x & 450 & 993 & 544 \\
KLP5002x & 299 & 1109 & 811 \\
KLP5006x & 670 & 1343 & 674 \\
KLP6007x & 474 & 1028 & 555 \\
KLP6019x & 785 & 1698 & 914 \\
KLP6020x & 1070 & 1310 & 241 \\
KLP6020y & 1046 & 1301 & 256 \\
KLP6031x & 153 & 716 & 564 \\
KLP6031y & -731 & -210 & 512 \\
KLP6035 & -364 & 449 & 814 \\
KLP7010x & 1044 & 1417 & 374 \\
KLP7012x & 1089 & 1692 & 604 \\
KLP7019x & 1200 & 1574 & 375 \\
KLP7025x & 1105 & 1307 & 203 \\
KLP8007x & 493 & 880 & 388 \\
KLP8017x & 688 & 1314 & 627 \\
KLP8022x & 465 & 945 & 481 \\
KLP9026 & 196 & 877 & 682 \\
\hline
\end{tabular}


Table 11: Samples analyzed from Urgaat lava including the inside ring year, outside ring year, and number of years the sample covers

\begin{tabular}{lrrr}
\multicolumn{4}{l}{ Urgaat Lava Pine } \\
\hline Sample ID & Inside & Outside & Years \\
\hline ULP3002x & 362 & 1080 & 719 \\
ULP3002Y & 345 & 855 & 511 \\
ULP3002z & 51 & 329 & 279 \\
ULP4003x & 920 & 1310 & 391 \\
ULP4010x & 591 & 1517 & 927 \\
ULP4018x & 508 & 1200 & 693 \\
ULP4020x & 230 & 766 & 537 \\
ULP4028x & -179 & 725 & 905 \\
ULP5008x & 1596 & 1839 & 244 \\
ULP5018x & 328 & 955 & 628 \\
ULP5028x & 528 & 1150 & 623 \\
ULP6005x & 528 & 880 & 353 \\
ULP6011x & 1471 & 1980 & 510 \\
ULP6013x & 1196 & 1535 & 340 \\
ULP6013y & 869 & 1454 & 586 \\
ULP6021x & 480 & 871 & 392 \\
ULP6023x & 1118 & 1762 & 645 \\
ULP6035x & 1173 & 1494 & 322 \\
ULP6045x & 1047 & 1661 & 615 \\
ULP6049x & 1023 & 1418 & 396 \\
ULP6053x & 257 & 946 & 690 \\
ULP6059x & 1128 & 1667 & 540 \\
ULP6063x & 171 & 766 & 596 \\
ULP7020x & 491 & 1044 & 554 \\
ULP7026x & 768 & 1624 & 857 \\
\hline
\end{tabular}


Table 12: Observed and total sample depth for Khorgo lava and Urgaat lava

\begin{tabular}{|c|c|c|c|c|}
\hline Year & $\begin{array}{c}\text { Khorgo } \\
\text { Observed } \\
\text { Sample Depth }\end{array}$ & $\begin{array}{l}\text { Khorgo Total } \\
\text { Sample Depth }\end{array}$ & $\begin{array}{c}\text { Urgaat } \\
\text { Observed } \\
\text { Sample Depth }\end{array}$ & $\begin{array}{l}\text { Urgaat Total } \\
\text { Sample Depth }\end{array}$ \\
\hline-426 & 1 & 3 & NA & NA \\
\hline-44 & 1 & 10 & 1 & 2 \\
\hline 87 & 2 & 15 & 2 & 2 \\
\hline 169 & 4 & 18 & 2 & 3 \\
\hline 266 & 5 & 25 & 5 & 6 \\
\hline 433 & 9 & 36 & 7 & 9 \\
\hline 536 & 12 & 43 & 12 & 16 \\
\hline 540 & 12 & 45 & 12 & 16 \\
\hline 574 & 13 & 46 & 12 & 18 \\
\hline 626 & 13 & 47 & 13 & 21 \\
\hline 682 & 14 & 48 & 13 & 22 \\
\hline 939 & 9 & 56 & 10 & 26 \\
\hline 1108 & 11 & 60 & 9 & 22 \\
\hline 1171 & 11 & 65 & 9 & 25 \\
\hline 1230 & 13 & 68 & 12 & 26 \\
\hline 1258 & 13 & 89 & 12 & 28 \\
\hline 1286 & 13 & 72 & 12 & 28 \\
\hline 1345 & 8 & 65 & 11 & 29 \\
\hline 1458 & 6 & 61 & 8 & 30 \\
\hline 1601 & 2 & 51 & 6 & 31 \\
\hline 1641 & 2 & 55 & 6 & 32 \\
\hline 1695 & 2 & 59 & 3 & 28 \\
\hline 1783 & 1 & 50 & 2 & 25 \\
\hline 1809 & 1 & 42 & 2 & 25 \\
\hline 1815 & 1 & 42 & 2 & 25 \\
\hline
\end{tabular}


I computed the statistical significance of receiving a false ring and absent ring using a chi-square test for each anatomy at each location. For false rings, I counted the observed false rings and total number of samples observed for the four years before the eruption, the year of the eruption, and four years after the eruption for each eruption event (the same nine-year window as SEA). The chi-square test compared the false rings before the eruptions (four years before) to the year of the eruption and four years after (five-year window). I compared the frequency of events during the years preceding the eruptions and the years following the eruptions (presumably influenced by the eruptions).

For absent rings, I used the COFECHA output that reports the total number of absent rings in the chronology along with the total number of rings for each calendar year in the chronology. Due to this, the sample size will not be the same as the false rings analysis. I analyzed the same nine-year window as the false rings analysis for each of the eruptions. This provided me with the observed values used to calculate the chi-square value. 


\section{Results}

\section{Volcanic Eruptions During the Instrumental Period in Mongolia}

The composite analyses performed in GrADS using CRU temperature and CRU scPDSI show little change in climate following volcanic eruptions during the modern instrumental period in Mongolia (Figures 3 - 6). The composite analyses following the three tropical eruptions show an increase of up to an scPDSI value of two in central and northern Mongolia. A small region in central Mongolia was found to be statistically significantly wetter $(\mathrm{p} \leq 0.05)$. In terms of temperature, the composite analyses show that most of Mongolia, especially central Mongolia, experienced a $\sim 0.1^{\circ}-0.3^{\circ} \mathrm{C}$ cooling in the year of the eruption though results were not statistically significant (significance set at $\mathrm{p} \leq 0.05$ ). Southeast and southwest Mongolia experienced a statistically insignificant $0.2^{\circ} \mathrm{C}$ warming. Results of the composite analysis following just the 1991 Mount Pinatubo eruption show the majority of Mongolia being wetter by scPDSI values of one to three. Only small regions of Mongolia were drier following the eruption by scPDSI value of negative one including southeast Mongolia and small patches in southern, central, and western Mongolia. We found a warming trend in the majority of Mongolia of up to $1.0^{\circ} \mathrm{C}$ with only a small region in eastern Mongolia experiencing a cooling of about $0.8^{\circ} \mathrm{C}$. Significance testing was not performed while analyzing the Mount Pinatubo eruption due to the sample size. 
Volcanic Eruption Induced scPDSI Difference with 3 Tropical Eruptions
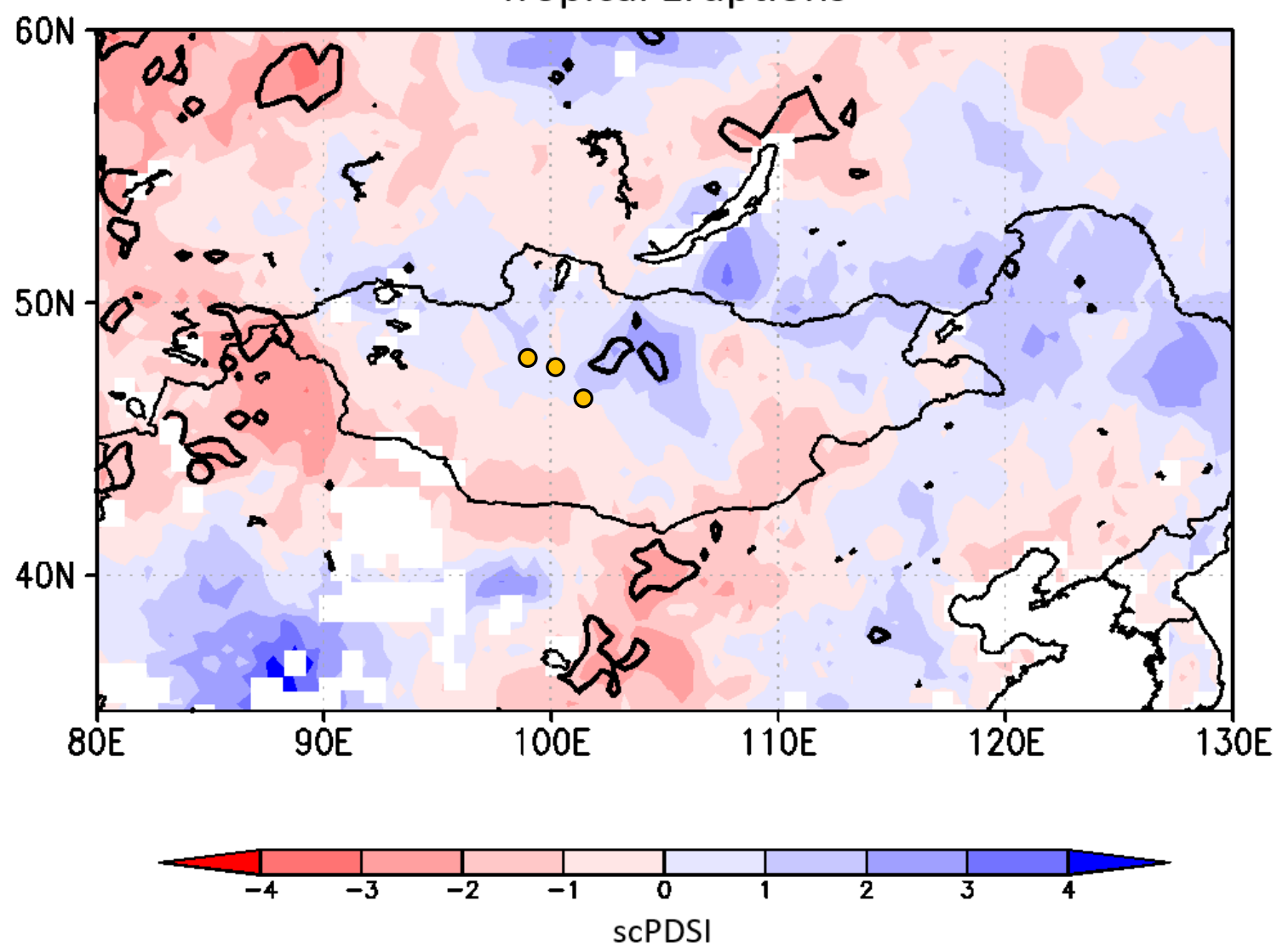

Figure 3: scPDSI composite difference using the 1963, 1982, and 1991 eruptions with a 54-year mean. Yellow dots represent the approximate locations of the three study sites 


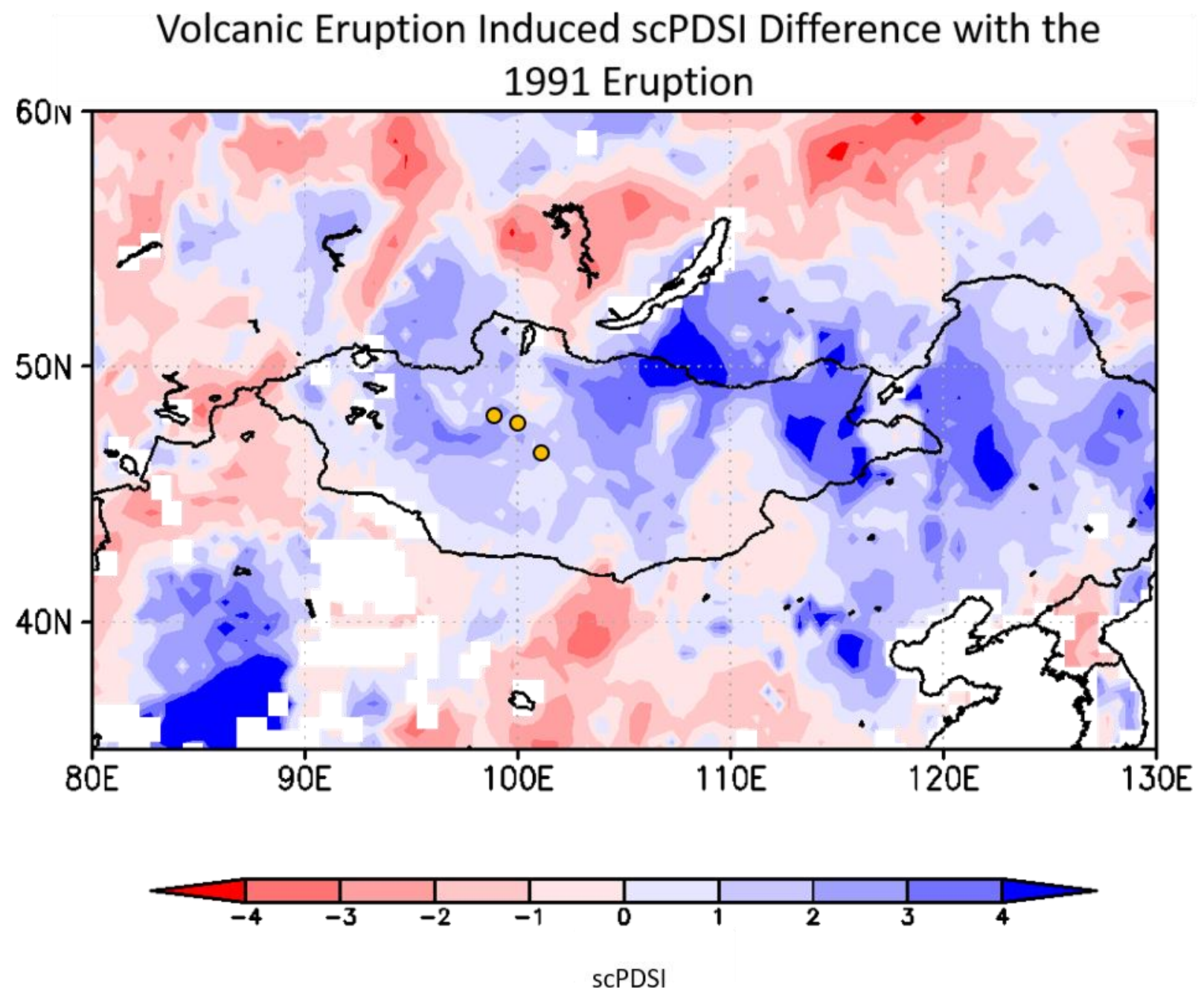

Figure 4: scPDSI composite difference comparing the 1991 eruption with a 54-year mean. Yellow dots represent the approximate locations of the three study sites 


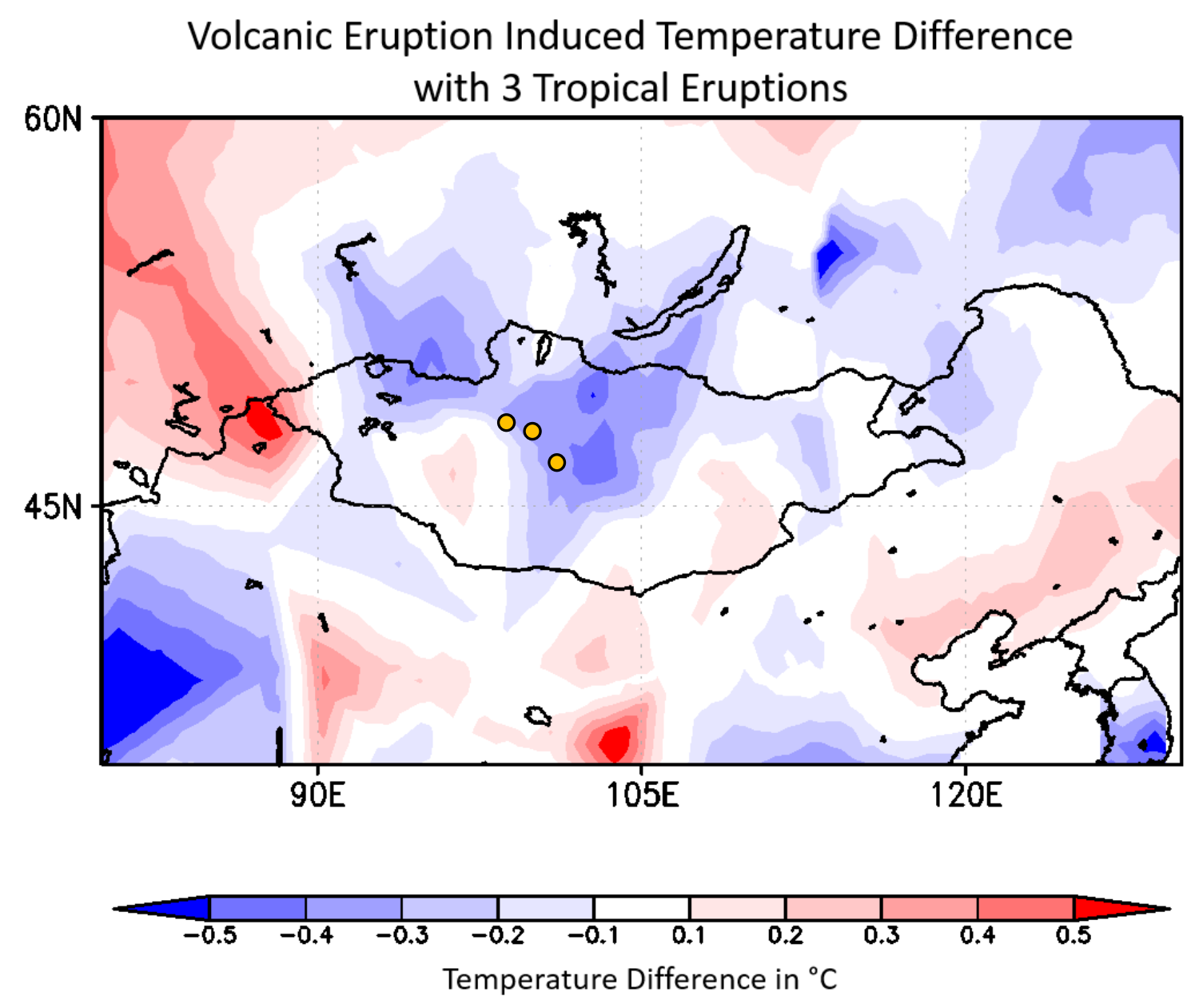

Figure 5: Temperature difference between the 1963, 1982, and 1991 eruptions with a 54-year average. Yellow dots represent the approximate locations of the three study sites 


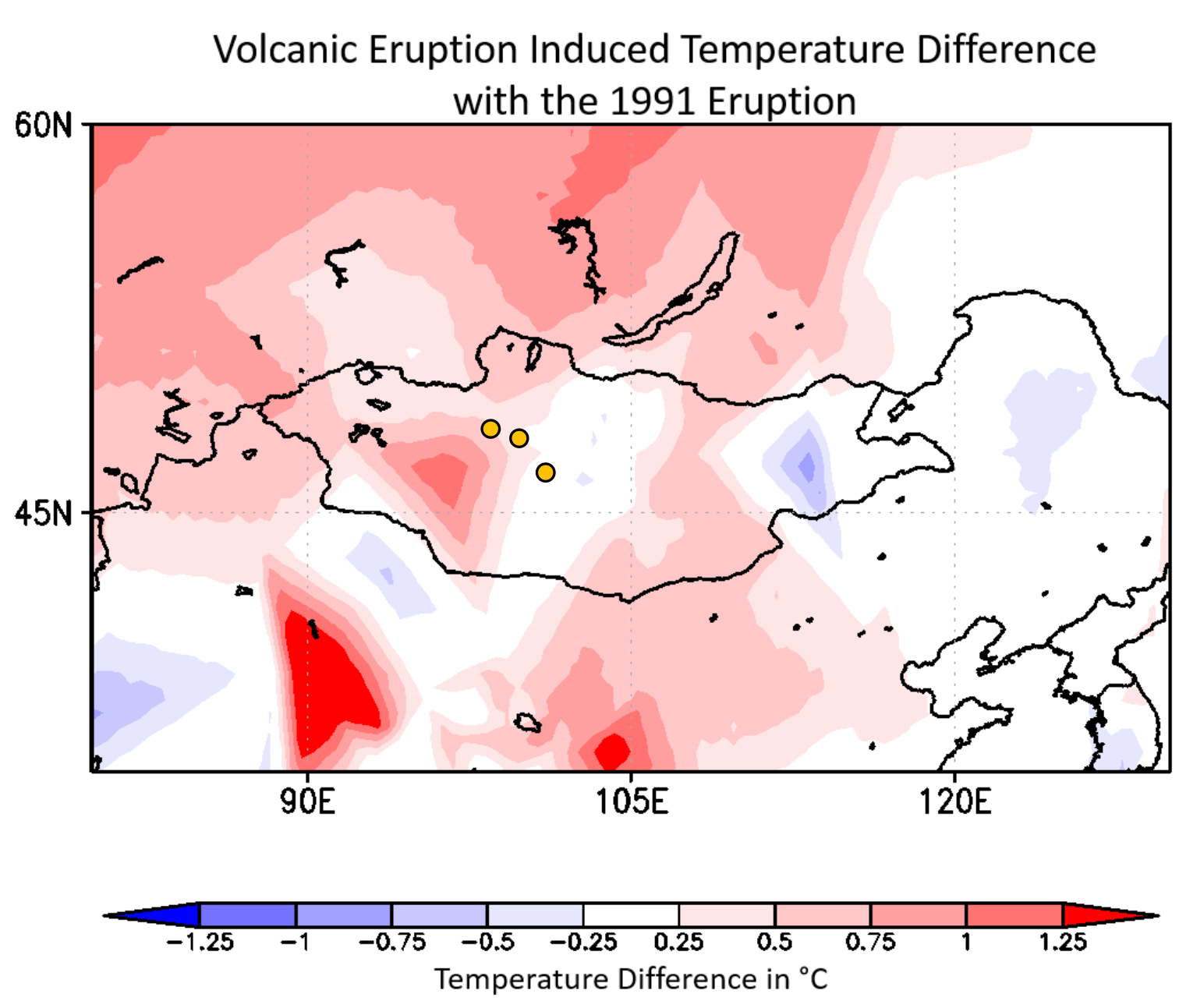

Figure 6: Temperature difference between the 1991 eruption and 54-year average. Yellow dots represent the approximate locations of the three study sites 


\section{SEA Results}

I observed no clear evidence of volcanic eruption induced temperature or moisture availability differences at Sol Dav, Khorgo lava, and Urgaat lava during the four SEA runs (Figures 7 - 18). During run one, (the complete volcanic eruption series) reconstructed scPDSI values at Khorgo lava and Urgaat lava are slightly lower the year after the eruption. At Khorgo lava, the second year after the eruption scPDSI values return to near average while Urgaat lava continues to become drier. Year three is slightly wetter than average at Khorgo lava and Urgaat lava. All these fell within the 95\% confidence levels. I observed no statistically significant differences in index values at Sol Dav (temperature-sensitive location) except for in year four. However, based on previous literature, we would consider year four to be outside the realm of volcanic-induced climate variation. Years negative three to one show in increase in index value, thus an increase in ring width. Years zero to two hover slightly below the mean index value of 0.0 with a gradual decrease from year three to year four with an index value of about -0.5 . The following three runs resulted in similar patterns of climate variability during the nine-year window. Most notably, results for the top 10 largest eruptions for both Khorgo lava and Urgaat lava were not significant at the $95 \%$ level. Results for the top five largest eruptions were also statistically insignificant at the $95 \%$ level but showed slightly more volcanic eruption induced moisture differences. They show recovery and decline patterns similar to the other SEA runs. SEA performed at Sol Dav during the top 10 and top five largest eruptions runs still fell within the $95 \%$ confidence levels, however, those values are close to being statistically significant while performing SEA with the top five largest eruptions. 


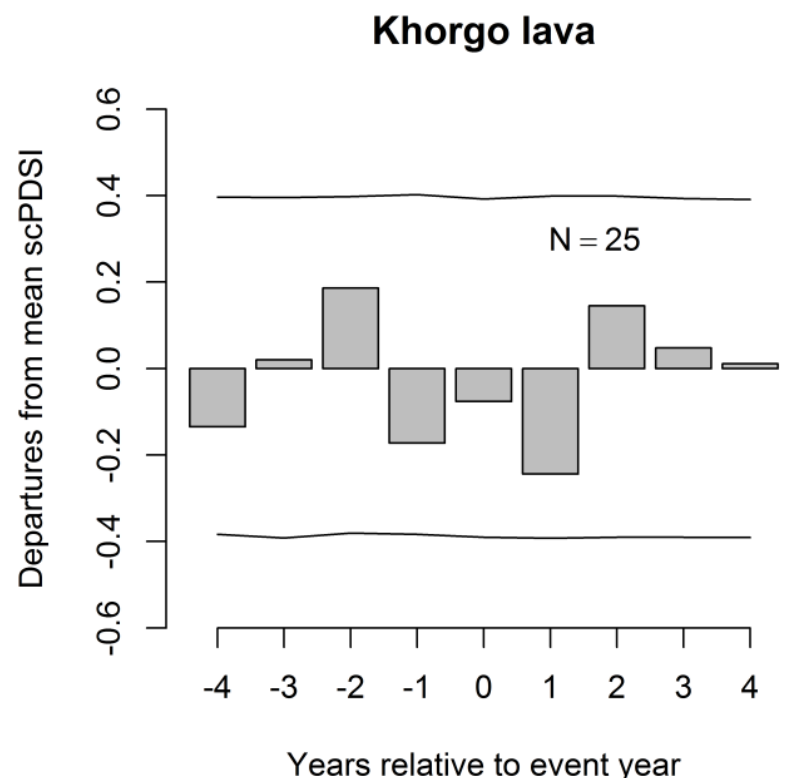

Figure 7: SEA results at Khorgo lava using all 25 eruptions. The lower and upper lines represent the $95 \%$ confidence limits

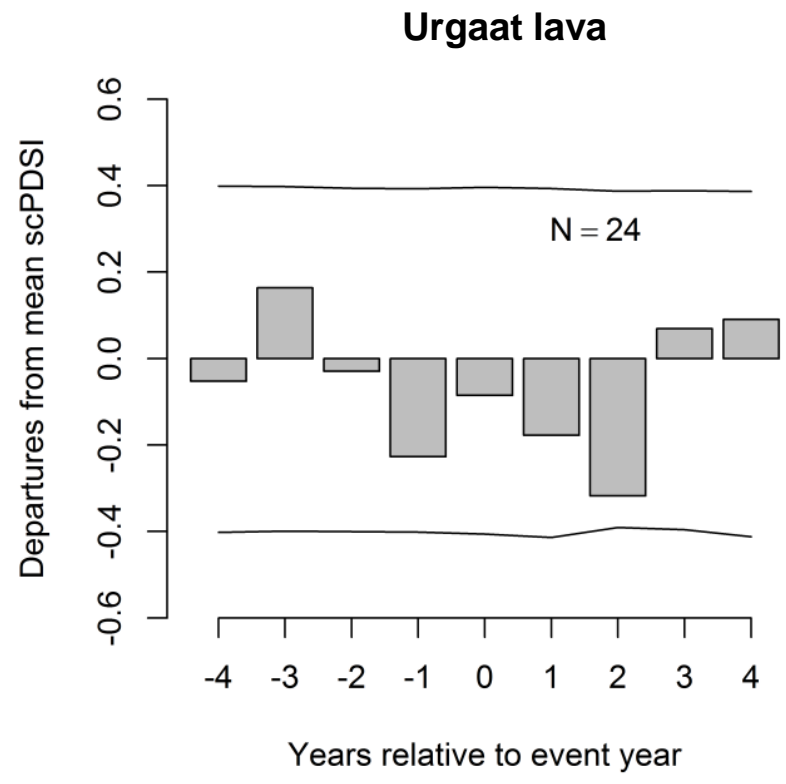

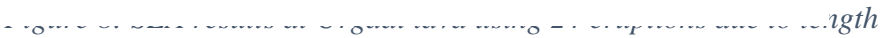
of reconstruction. The lower and upper lines represent the $95 \%$ confidence limits 


\section{Solongotyn Davaa}

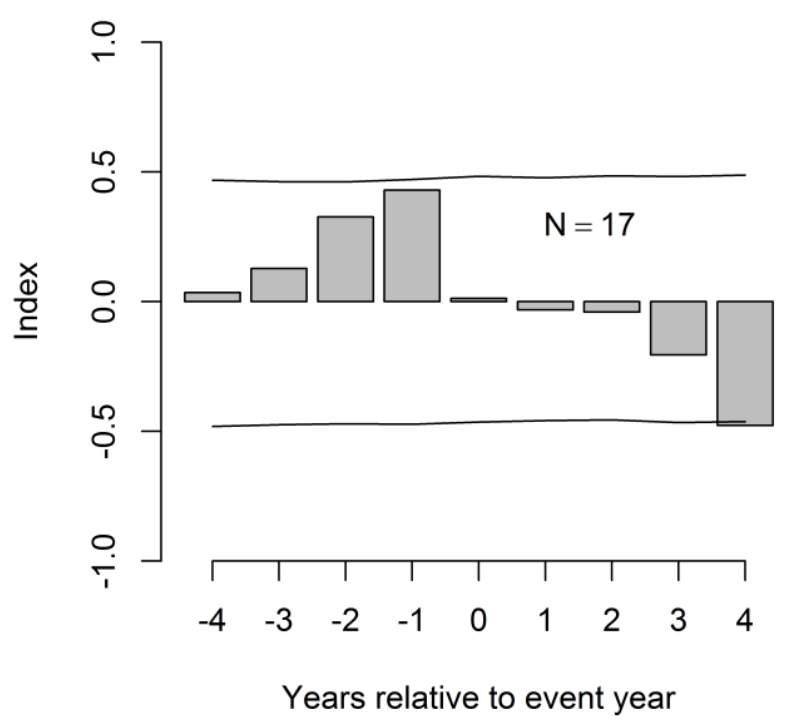

Figure 9: SEA results at Sol Dav using 17 eruptions due to length of chronology. The lower and upper lines represent the $95 \%$ confidence limits 


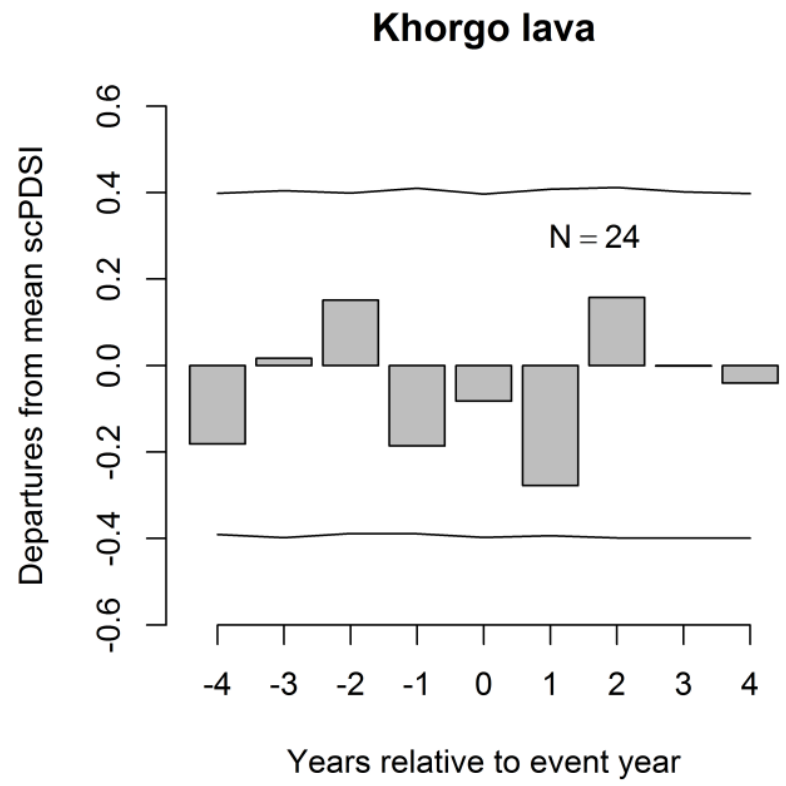

Figure 10: SEA performed at Khorgo lava using years in the reconstruction that has a sample depth of 10 or greater. The lower and upper lines represent the $95 \%$ confidence limits

\section{Urgaat lava}

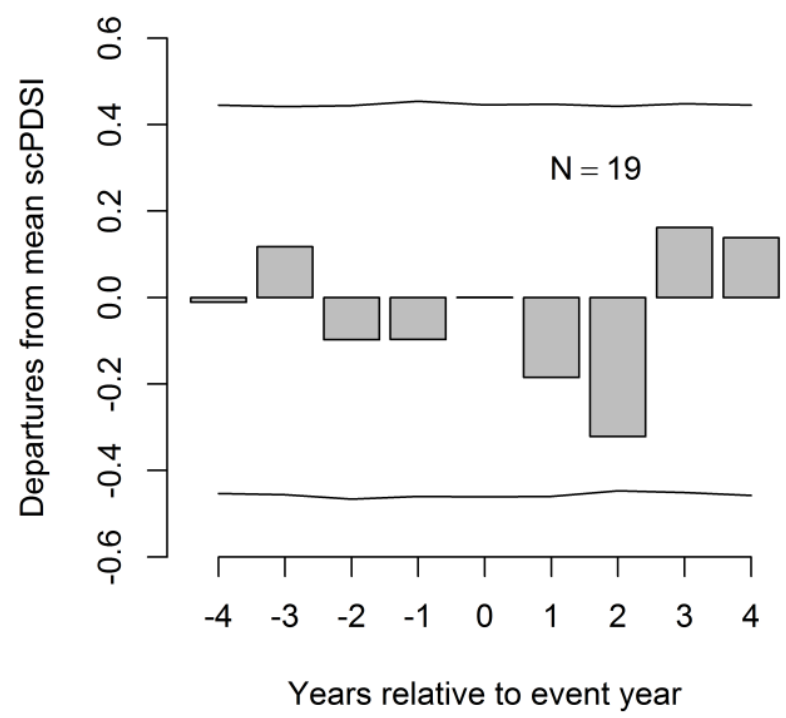

reconstruction that has a sample depth of 10 or greater. The lower and upper lines represent the $95 \%$ confidence limits 


\section{Solongotyn Davaa}

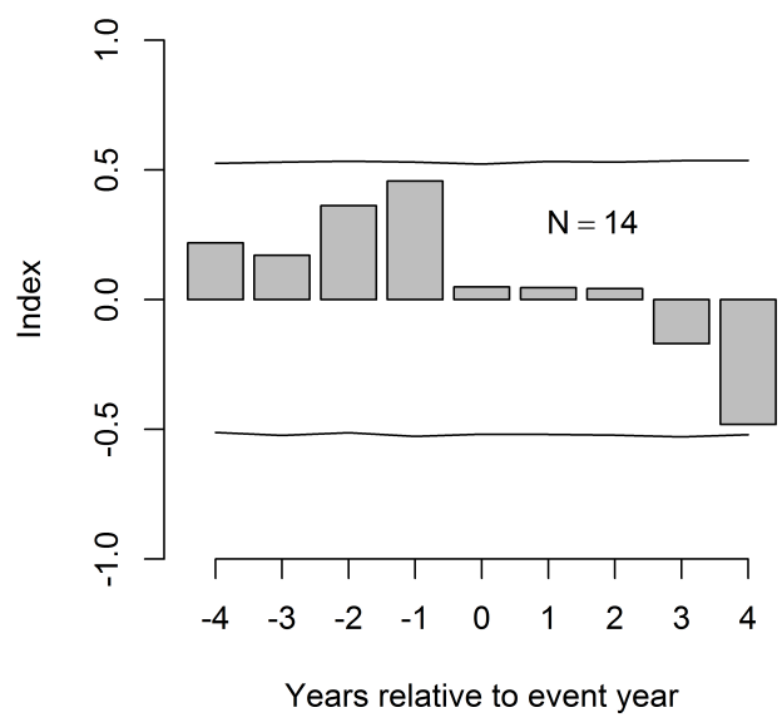

Figure 12: SEA performed at Sol Dav using years in the chronology that has a sample depth of 10 or greater. The lower and upper lines represent the $95 \%$ confidence limits 
Khorgo lava

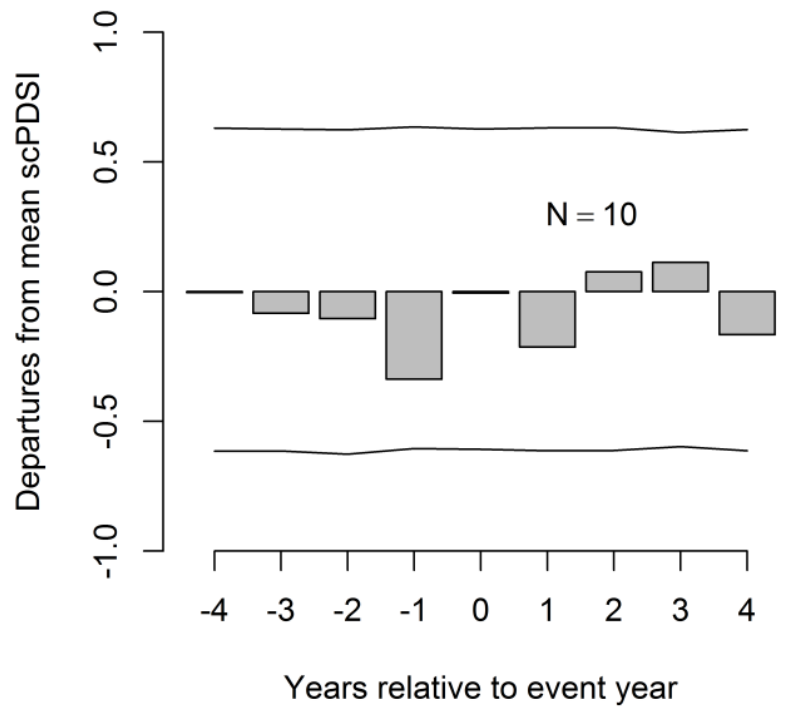

Figure 13: SEA using the 10 largest eruptions on the Sigl et al. (2015) table that also have at least 10 sample depth at Khorgo lava. The lower and upper lines represent the $95 \%$ confidence limits

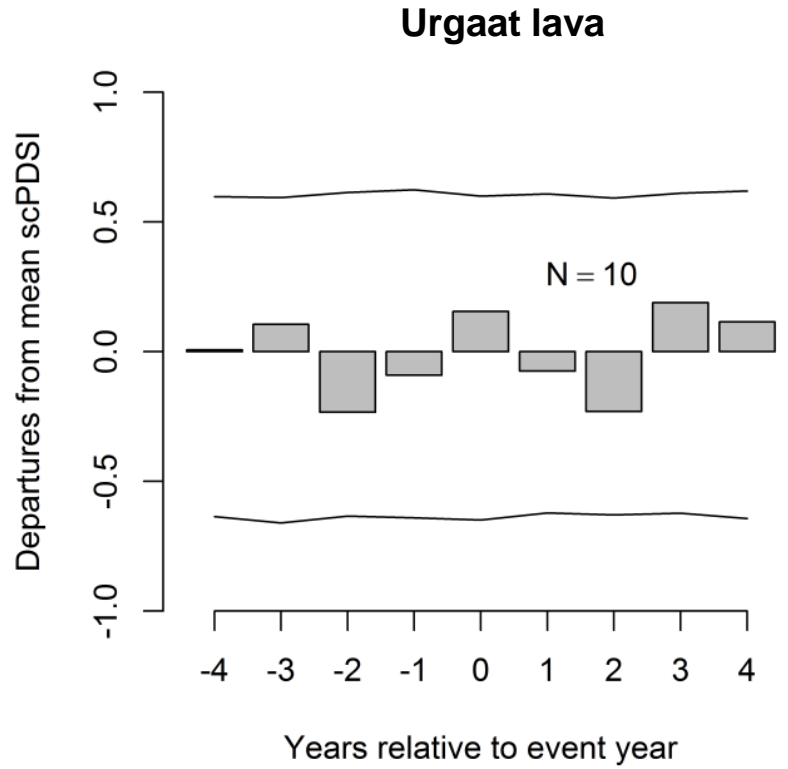

Figure 14: SEA using the 10 largest eruptions on the Sigl et al. (2015) table that also have at least 10 sample depth at Urgaat lava. The lower and upper lines represent the $95 \%$ confidence limits 


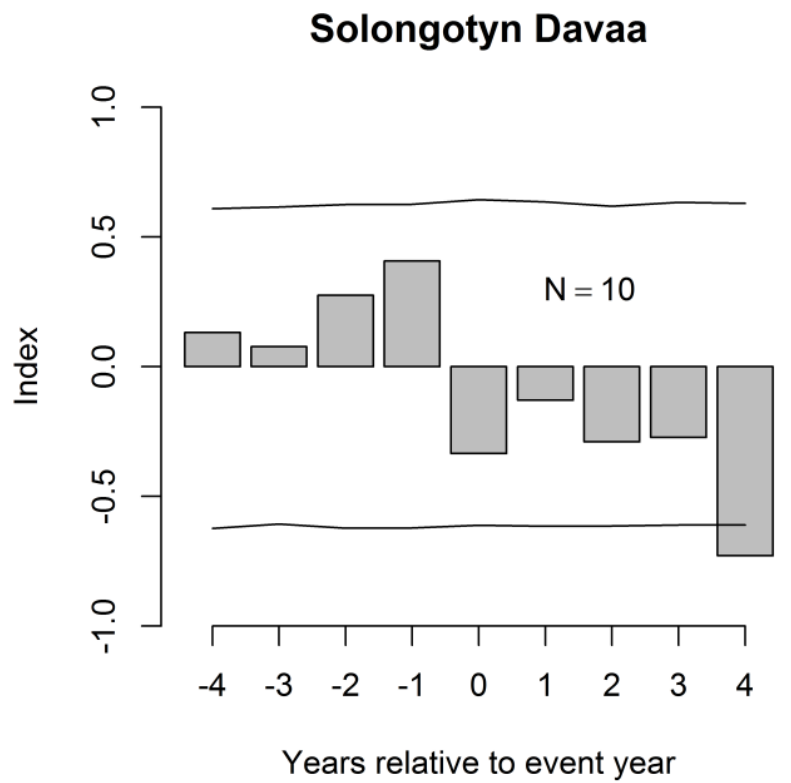

Figure 15: SEA using the 10 largest eruptions on the Sigl et al. (2015) table that also have at least 10 sample depth at Sol Dav. The lower and upper lines represent the $95 \%$ confidence limits 


\section{Khorgo lava}

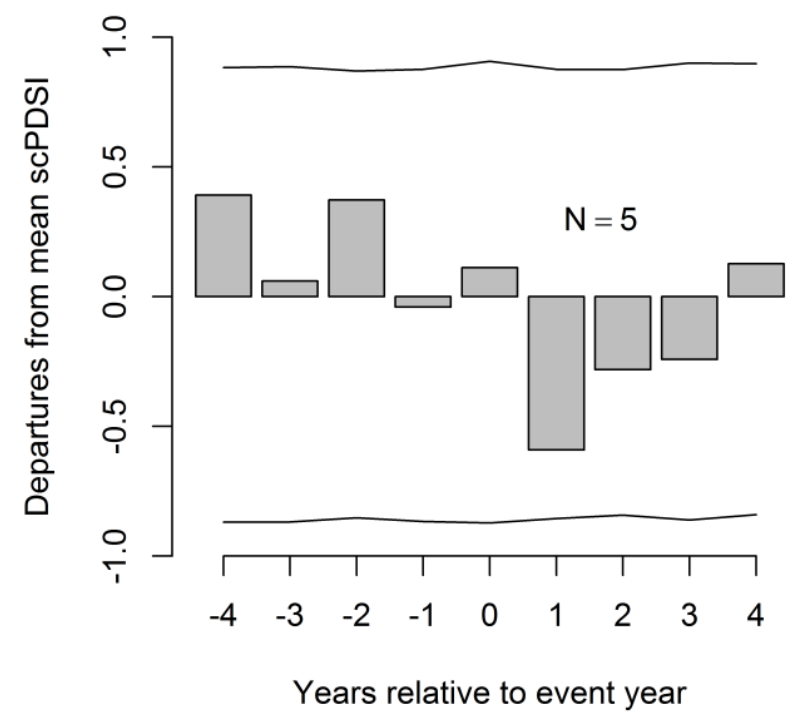

Figure 16: SEA using the 5 largest eruptions on the Sigl et al. (2015) table that also have at least 10 sample depth at Khorgo lava. The lower and upper lines represent the $95 \%$ confidence limits

\section{Urgaat lava}

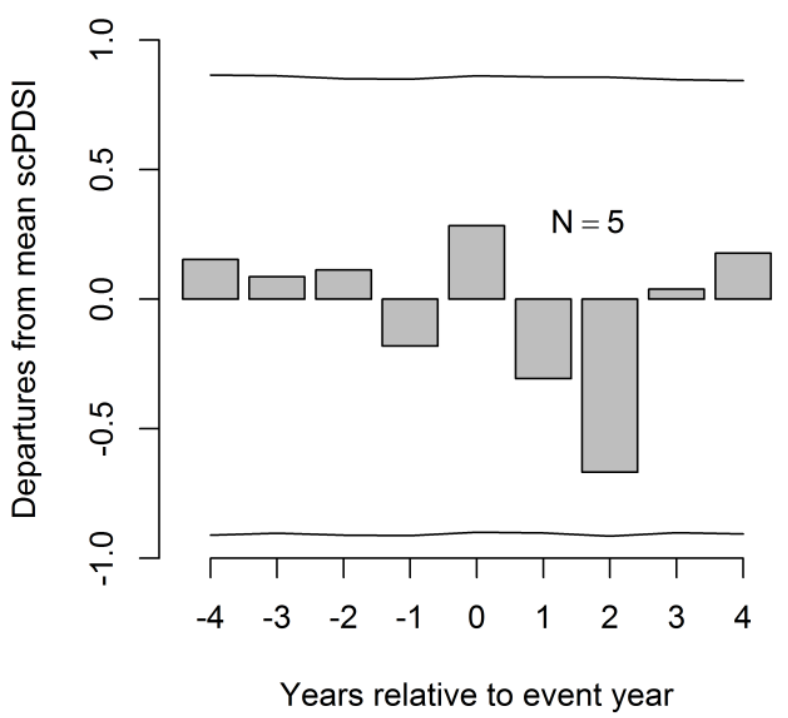

Figure 17: SEA using the 5 largest eruptions on the Sigl et al. (2015) table that also have at least 10 sample depth at Urgaat lava. The lower and upper lines represent the $95 \%$ confidence limits 


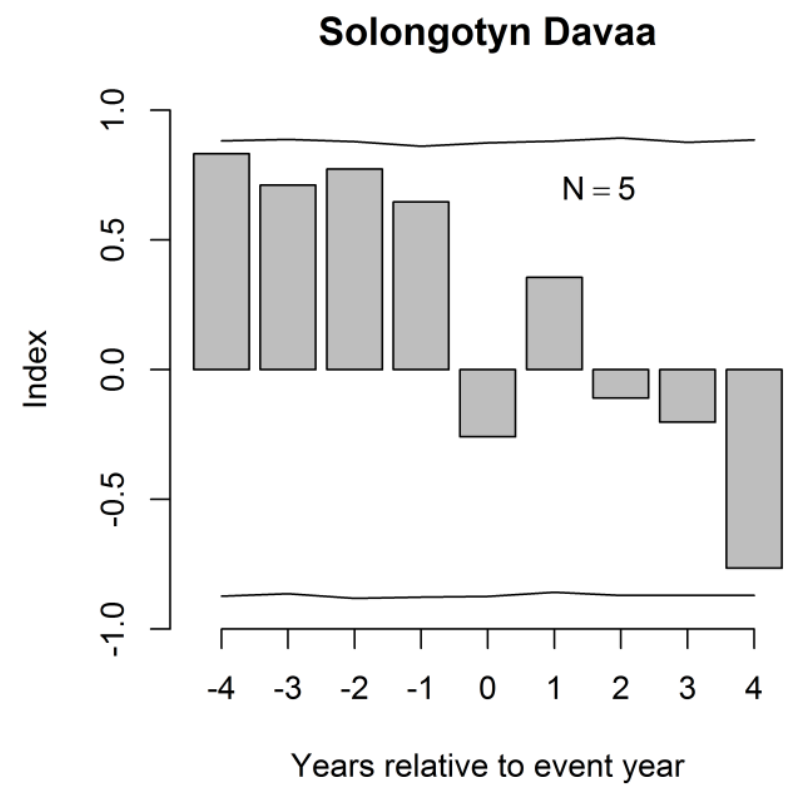

Figure 18: SEA using the 5 largest eruptions on the Sigl et al. (2015) table that also have at least 10 sample depth at Sol Dav. The lower and upper lines represent the $95 \%$ confidence limits 


\section{Tree-ring Anatomy Results}

I found that during the tree-ring anatomy analysis, Khorgo lava and Urgaat lava tree growth were affected by select eruption events (Tables 13 - 16, Figures 19 - 20). False rings were detected at Khorgo lava for eruption event years $-426,87,169,433,536,540,574,626,682,939,1108,1230,1258,1345$, and 1458 and at Urgaat lava for years $87,540,939,1258$, and 1345. A chi-square test shows that year two at Khorgo lava has a statistically significant difference in false rings when compared to non-eruption induced years ( $\mathrm{p}$-value $=0.013$ ) (Table 17). All years following an eruption at Urgaat lava have p-values of greater than 0.05 , thus we do not have enough evidence to say that it is statistically different from noneruption induced years.

Along with false rings, absent rings were detected for eruption event years 87, 1230, 1258, 1286, 1345, 1641, 1695, 1809, and 1815 at Khorgo lava (Table 15). At Urgaat lava the event years that showed absent rings during the five-year post-eruption period include years 939 and 1258 (Table 16). All other eruption event years that were available during this chronology did not have any missing rings present. Chi-square test showed that the second year following the eruption have statistically significant difference in absent rings when compared to the rest of the chronology (p-value at Khorgo lava $=0.019$ and $p$-value at Urgaat lava $=0.033)($ Table 17) 
Table 13: Percent of observed samples showing false rings at Khorgo lava during the year of the eruption and four years after.

* resembles year of eruption

\begin{tabular}{|c|c|c|c|c|c|c|c|c|c|}
\hline Year & $\begin{array}{c}\% \\
\text { Showing }\end{array}$ & Year & $\begin{array}{c}\% \\
\text { Showing }\end{array}$ & Year & $\begin{array}{c}\% \\
\text { Showing }\end{array}$ & Year & $\begin{array}{c}\% \\
\text { Showing }\end{array}$ & Year & $\begin{array}{c}\% \\
\text { Showing }\end{array}$ \\
\hline$*_{-426}$ & $0 \%$ & $* 433$ & $0 \%$ & $* 682$ & $7 \%$ & $* 1258$ & $0 \%$ & $* 1641$ & $0 \%$ \\
\hline-425 & $0 \%$ & 434 & $0 \%$ & 683 & $0 \%$ & 1259 & $15 \%$ & 1642 & $0 \%$ \\
\hline-424 & $100 \%$ & 435 & $0 \%$ & 684 & $0 \%$ & 1260 & $0 \%$ & 1643 & $0 \%$ \\
\hline-423 & $0 \%$ & 436 & $22 \%$ & 685 & $0 \%$ & 1261 & $8 \%$ & 1644 & $0 \%$ \\
\hline-422 & $0 \%$ & 437 & $11 \%$ & 686 & $0 \%$ & 1262 & $8 \%$ & 1645 & $0 \%$ \\
\hline$*_{-44}$ & $0 \%$ & $* 536$ & $0 \%$ & $* 939$ & $0 \%$ & $* 1286$ & $0 \%$ & *1695 & $0 \%$ \\
\hline-43 & $0 \%$ & 537 & $8 \%$ & 940 & $0 \%$ & 1287 & $0 \%$ & 1696 & $0 \%$ \\
\hline-42 & $0 \%$ & 538 & $0 \%$ & 941 & $22 \%$ & 1288 & $0 \%$ & 1697 & $0 \%$ \\
\hline-41 & $0 \%$ & 639 & $0 \%$ & 942 & $11 \%$ & 1289 & $0 \%$ & 1698 & $0 \%$ \\
\hline-40 & $0 \%$ & $* 540$ & $0 \%$ & 943 & $0 \%$ & 1290 & $0 \%$ & 1699 & $0 \%$ \\
\hline$* 87$ & $50 \%$ & 541 & $0 \%$ & $* 1108$ & $0 \%$ & $* 1345$ & $0 \%$ & *1783 & $0 \%$ \\
\hline 88 & $0 \%$ & 542 & $42 \%$ & 1109 & $0 \%$ & 1346 & $0 \%$ & 1784 & $0 \%$ \\
\hline 89 & $0 \%$ & 543 & $8 \%$ & 1110 & $27 \%$ & 1347 & $63 \%$ & 1785 & $0 \%$ \\
\hline 90 & $0 \%$ & 544 & $0 \%$ & 1111 & $0 \%$ & 1348 & $0 \%$ & 1786 & $0 \%$ \\
\hline 91 & $0 \%$ & $* 574$ & $0 \%$ & 1112 & $0 \%$ & 1349 & $38 \%$ & 1787 & $0 \%$ \\
\hline *169 & $25 \%$ & 575 & $0 \%$ & $* 1171$ & $0 \%$ & $* 1458$ & $0 \%$ & *1809 & $0 \%$ \\
\hline 170 & $25 \%$ & 576 & $0 \%$ & 1172 & $0 \%$ & 1459 & $0 \%$ & 1810 & $0 \%$ \\
\hline 171 & $0 \%$ & 577 & $0 \%$ & 1173 & $0 \%$ & 1460 & $0 \%$ & 1811 & $0 \%$ \\
\hline 172 & $0 \%$ & 578 & $38 \%$ & 1174 & $0 \%$ & 1461 & $0 \%$ & 1812 & $0 \%$ \\
\hline 173 & $0 \%$ & $* 626$ & $0 \%$ & 1175 & $0 \%$ & 1462 & $17 \%$ & 1813 & $0 \%$ \\
\hline$* 266$ & $0 \%$ & 627 & $0 \%$ & $* 1230$ & $0 \%$ & *1601 & $0 \%$ & *1815 & $0 \%$ \\
\hline 267 & $0 \%$ & 628 & $0 \%$ & 1231 & $23 \%$ & 1602 & $0 \%$ & 1816 & $0 \%$ \\
\hline 268 & $0 \%$ & 629 & $0 \%$ & 1232 & $0 \%$ & 1603 & $0 \%$ & 1817 & $0 \%$ \\
\hline 269 & $0 \%$ & 630 & $8 \%$ & 1233 & $0 \%$ & 1604 & $0 \%$ & 1818 & $0 \%$ \\
\hline 270 & $0 \%$ & & & 1234 & $0 \%$ & 1605 & $0 \%$ & 1819 & $0 \%$ \\
\hline
\end{tabular}


Table 14: Percent of observed samples showing false rings at Urgaat lava during the year of the eruption and four years after.

* resembles year of eruption

\begin{tabular}{|c|c|c|c|c|c|c|c|c|c|}
\hline \multicolumn{10}{|c|}{ Urgaat Lava Pine False Rings } \\
\hline Year & $\begin{array}{c}\% \\
\text { Showing }\end{array}$ & Year & $\begin{array}{c}\% \\
\text { Showing }\end{array}$ & Year & $\begin{array}{c}\% \\
\text { Showing }\end{array}$ & Year & $\begin{array}{c}\% \\
\text { Showing }\end{array}$ & Year & $\begin{array}{c}\% \\
\text { Showing }\end{array}$ \\
\hline$*-426$ & NA & $* 433$ & $0 \%$ & $* 682$ & $0 \%$ & $* 1258$ & $0 \%$ & *1641 & $0 \%$ \\
\hline-425 & NA & 434 & $0 \%$ & 683 & $0 \%$ & 1259 & $0 \%$ & 1642 & $0 \%$ \\
\hline-424 & NA & 435 & $0 \%$ & 684 & $0 \%$ & 1260 & $8 \%$ & 1643 & $0 \%$ \\
\hline-423 & NA & 436 & $0 \%$ & 685 & $0 \%$ & 1261 & $0 \%$ & 1644 & $0 \%$ \\
\hline-422 & NA & 437 & $0 \%$ & 686 & $0 \%$ & 1262 & $0 \%$ & 1645 & $0 \%$ \\
\hline$*_{-}^{*} 44$ & $0 \%$ & $* 536$ & $0 \%$ & *939 & $0 \%$ & $* 1286$ & $0 \%$ & $* 1695$ & $0 \%$ \\
\hline-43 & $0 \%$ & 537 & $0 \%$ & 940 & $0 \%$ & 1287 & $0 \%$ & 1696 & $0 \%$ \\
\hline-42 & $0 \%$ & 538 & $0 \%$ & 941 & $11 \%$ & 1288 & $0 \%$ & 1697 & $0 \%$ \\
\hline-41 & $0 \%$ & 639 & $0 \%$ & 942 & $0 \%$ & 1289 & $0 \%$ & 1698 & $0 \%$ \\
\hline-40 & $0 \%$ & $* 540$ & $0 \%$ & 943 & $0 \%$ & 1290 & $0 \%$ & 1699 & $0 \%$ \\
\hline$* 87$ & $50 \%$ & 541 & $0 \%$ & *1108 & $0 \%$ & *1345 & $0 \%$ & *1783 & $0 \%$ \\
\hline 88 & $0 \%$ & 542 & $8 \%$ & 1109 & $0 \%$ & 1346 & $0 \%$ & 1784 & $0 \%$ \\
\hline 89 & $0 \%$ & 543 & $0 \%$ & 1110 & $0 \%$ & 1347 & $9 \%$ & 1785 & $0 \%$ \\
\hline 90 & $0 \%$ & 544 & $0 \%$ & 1111 & $0 \%$ & 1348 & $0 \%$ & 1786 & $0 \%$ \\
\hline 91 & $0 \%$ & $* 574$ & $0 \%$ & 1112 & $0 \%$ & 1349 & $0 \%$ & 1787 & $0 \%$ \\
\hline *169 & $0 \%$ & 575 & $0 \%$ & $* 1171$ & $0 \%$ & $* 1458$ & $0 \%$ & *1809 & $0 \%$ \\
\hline 170 & $0 \%$ & 576 & $0 \%$ & 1172 & $0 \%$ & 1459 & $0 \%$ & 1810 & $0 \%$ \\
\hline 171 & $0 \%$ & 577 & $0 \%$ & 1173 & $0 \%$ & 1460 & $0 \%$ & 1811 & $0 \%$ \\
\hline 172 & $0 \%$ & 578 & $0 \%$ & 1174 & $0 \%$ & 1461 & $0 \%$ & 1812 & $0 \%$ \\
\hline 173 & $0 \%$ & $* 626$ & $0 \%$ & 1175 & $0 \%$ & 1462 & $0 \%$ & 1813 & $0 \%$ \\
\hline *266 & $0 \%$ & 627 & $0 \%$ & $* 1230$ & $0 \%$ & $* 1601$ & $0 \%$ & *1815 & $0 \%$ \\
\hline 267 & $0 \%$ & 628 & $0 \%$ & 1231 & $0 \%$ & 1602 & $0 \%$ & 1816 & $0 \%$ \\
\hline 268 & $0 \%$ & 629 & $0 \%$ & 1232 & $0 \%$ & 1603 & $0 \%$ & 1817 & $0 \%$ \\
\hline 269 & $0 \%$ & 630 & $0 \%$ & 1233 & $0 \%$ & 1604 & $0 \%$ & 1818 & $0 \%$ \\
\hline 270 & $0 \%$ & & & 1234 & $0 \%$ & 1605 & $0 \%$ & 1819 & $0 \%$ \\
\hline
\end{tabular}


Table 15: Percent of total samples in chronology showing absent rings at Khorgo lava during the year of the eruption and four years after.

* resembles year of eruption

\begin{tabular}{|c|c|c|c|c|c|c|c|c|c|}
\hline Year & $\begin{array}{c}\% \\
\text { Showing }\end{array}$ & Year & $\begin{array}{c}\% \\
\text { Showing }\end{array}$ & Year & $\begin{array}{c}\% \\
\text { Showing }\end{array}$ & Year & $\begin{array}{c}\% \\
\text { Showing }\end{array}$ & Year & $\begin{array}{c}\% \\
\text { Showing }\end{array}$ \\
\hline$*_{-426}$ & $0 \%$ & $* 433$ & $0 \%$ & $* 682$ & $0 \%$ & $* 1258$ & $0 \%$ & $* 1641$ & $5.5 \%$ \\
\hline-425 & $0 \%$ & 434 & $0 \%$ & 683 & $0 \%$ & 1259 & $14.5 \%$ & 1642 & $1.8 \%$ \\
\hline-424 & $0 \%$ & 435 & $0 \%$ & 684 & $0 \%$ & 1260 & $1.4 \%$ & 1643 & $0 \%$ \\
\hline-423 & $0 \%$ & 436 & $0 \%$ & 685 & $0 \%$ & 1261 & $0 \%$ & 1644 & $0 \%$ \\
\hline-422 & $0 \%$ & 437 & $0 \%$ & 686 & $0 \%$ & 1262 & $0 \%$ & 1645 & $0 \%$ \\
\hline$*-44$ & $0 \%$ & $* 536$ & $0 \%$ & *939 & $0 \%$ & $* 1286$ & $0 \%$ & $* 1695$ & $0 \%$ \\
\hline-43 & $0 \%$ & 537 & $0 \%$ & 940 & $0 \%$ & 1287 & $0 \%$ & 1696 & $0 \%$ \\
\hline-42 & $0 \%$ & 538 & $0 \%$ & 941 & $0 \%$ & 1288 & $0 \%$ & 1697 & $0 \%$ \\
\hline-41 & $0 \%$ & 639 & $0 \%$ & 942 & $0 \%$ & 1289 & $0 \%$ & 1698 & $1.7 \%$ \\
\hline-40 & $0 \%$ & $* 540$ & $0 \%$ & 943 & $0 \%$ & 1290 & $1.4 \%$ & 1699 & $0 \%$ \\
\hline$* 87$ & $0 \%$ & 541 & $0 \%$ & *1108 & $0 \%$ & $* 1345$ & $0 \%$ & *1783 & $0 \%$ \\
\hline 88 & $6.7 \%$ & 542 & $0 \%$ & 1109 & $0 \%$ & 1346 & $0 \%$ & 1784 & $0 \%$ \\
\hline 89 & $0 \%$ & 543 & $0 \%$ & 1110 & $0 \%$ & 1347 & $0 \%$ & 1785 & $0 \%$ \\
\hline 90 & $0 \%$ & 544 & $0 \%$ & 1111 & $0 \%$ & 1348 & $0 \%$ & 1786 & $0 \%$ \\
\hline 91 & $0 \%$ & $* 574$ & $0 \%$ & 1112 & $0 \%$ & 1349 & $0 \%$ & 1787 & $0 \%$ \\
\hline *169 & $0 \%$ & 575 & $0 \%$ & *1171 & $0 \%$ & $* 1458$ & $0 \%$ & *1809 & $0 \%$ \\
\hline 170 & $0 \%$ & 576 & $0 \%$ & 1172 & $0 \%$ & 1459 & $0 \%$ & 1810 & $0 \%$ \\
\hline 171 & $0 \%$ & 577 & $0 \%$ & 1173 & $0 \%$ & 1460 & $0 \%$ & 1811 & $0 \%$ \\
\hline 172 & $0 \%$ & 578 & $0 \%$ & 1174 & $0 \%$ & 1461 & $0 \%$ & 1812 & $2.4 \%$ \\
\hline 173 & $0 \%$ & $* 626$ & $0 \%$ & 1175 & $0 \%$ & 1462 & $0 \%$ & 1813 & $0 \%$ \\
\hline$* 266$ & $0 \%$ & 627 & $0 \%$ & $* 1230$ & $0 \%$ & $* 1601$ & $0 \%$ & $* 1815$ & $0 \%$ \\
\hline 267 & $0 \%$ & 628 & $0 \%$ & 1231 & $1.5 \%$ & 1602 & $0 \%$ & 1816 & $0 \%$ \\
\hline 268 & $0 \%$ & 629 & $0 \%$ & 1232 & $0 \%$ & 1603 & $0 \%$ & 1817 & $0 \%$ \\
\hline 269 & $0 \%$ & 630 & $0 \%$ & 1233 & $0 \%$ & 1604 & $0 \%$ & 1818 & $0 \%$ \\
\hline 270 & $0 \%$ & & & 1234 & $0 \%$ & 1605 & $0 \%$ & 1819 & $2.4 \%$ \\
\hline
\end{tabular}


Table 16: Percent of total samples in chronology showing absent rings at Urgaat lava during the year of the eruption and four years after.

* resembles year of eruption

\begin{tabular}{|c|c|c|c|c|c|c|c|c|c|}
\hline Year & $\begin{array}{c}\% \\
\text { Showing }\end{array}$ & Year & $\begin{array}{c}\% \\
\text { Showing }\end{array}$ & Year & $\begin{array}{c}\% \\
\text { Showing }\end{array}$ & Year & $\begin{array}{c}\% \\
\text { Showing }\end{array}$ & Year & $\begin{array}{c}\% \\
\text { Showing }\end{array}$ \\
\hline$*-426$ & NA & $* 433$ & $0 \%$ & $* 682$ & $0 \%$ & $* 1258$ & $0 \%$ & $* 1641$ & $0 \%$ \\
\hline-425 & NA & 434 & $0 \%$ & 683 & $0 \%$ & 1259 & $0 \%$ & 1642 & $0 \%$ \\
\hline-424 & NA & 435 & $0 \%$ & 684 & $0 \%$ & 1260 & $17.9 \%$ & 1643 & $0 \%$ \\
\hline-423 & NA & 436 & $0 \%$ & 685 & $0 \%$ & 1261 & $0 \%$ & 1644 & $0 \%$ \\
\hline-422 & NA & 437 & $0 \%$ & 686 & $0 \%$ & 1262 & $0 \%$ & 1645 & $0 \%$ \\
\hline$*_{-44}$ & $0 \%$ & $* 536$ & $0 \%$ & *939 & $0 \%$ & $* 1286$ & $0 \%$ & $* 1695$ & $0 \%$ \\
\hline-43 & $0 \%$ & 537 & $0 \%$ & 940 & $0 \%$ & 1287 & $0 \%$ & 1696 & $0 \%$ \\
\hline-42 & $0 \%$ & 538 & $0 \%$ & 941 & $3.8 \%$ & 1288 & $0 \%$ & 1697 & $0 \%$ \\
\hline-41 & $0 \%$ & 639 & $0 \%$ & 942 & $0 \%$ & 1289 & $0 \%$ & 1698 & $0 \%$ \\
\hline-40 & $0 \%$ & $* 540$ & $0 \%$ & 943 & $0 \%$ & 1290 & $0 \%$ & 1699 & $0 \%$ \\
\hline$* 87$ & $0 \%$ & 541 & $0 \%$ & $* 1108$ & $0 \%$ & $* 1345$ & $0 \%$ & $* 1783$ & $0 \%$ \\
\hline 88 & $0 \%$ & 542 & $0 \%$ & 1109 & $0 \%$ & 1346 & $0 \%$ & 1784 & $0 \%$ \\
\hline 89 & $0 \%$ & 543 & $0 \%$ & 1110 & $0 \%$ & 1347 & $0 \%$ & 1785 & $0 \%$ \\
\hline 90 & $0 \%$ & 544 & $0 \%$ & 1111 & $0 \%$ & 1348 & $0 \%$ & 1786 & $0 \%$ \\
\hline 91 & $0 \%$ & $* 574$ & $0 \%$ & 1112 & $0 \%$ & 1349 & $0 \%$ & 1787 & $0 \%$ \\
\hline *169 & $0 \%$ & 575 & $0 \%$ & $* 1171$ & $0 \%$ & $* 1458$ & $0 \%$ & $* 1809$ & $0 \%$ \\
\hline 170 & $0 \%$ & 576 & $0 \%$ & 1172 & $0 \%$ & 1459 & $0 \%$ & 1810 & $0 \%$ \\
\hline 171 & $0 \%$ & 577 & $0 \%$ & 1173 & $0 \%$ & 1460 & $0 \%$ & 1811 & $0 \%$ \\
\hline 172 & $0 \%$ & 578 & $0 \%$ & 1174 & $0 \%$ & 1461 & $0 \%$ & 1812 & $0 \%$ \\
\hline 173 & $0 \%$ & $* 626$ & $0 \%$ & 1175 & $0 \%$ & 1462 & $0 \%$ & 1813 & $0 \%$ \\
\hline$* 266$ & $0 \%$ & 627 & $0 \%$ & $* 1230$ & $0 \%$ & $* 1601$ & $0 \%$ & $* 1815$ & $0 \%$ \\
\hline 267 & $0 \%$ & 628 & $0 \%$ & 1231 & $0 \%$ & 1602 & $0 \%$ & 1816 & $0 \%$ \\
\hline 268 & $0 \%$ & 629 & $0 \%$ & 1232 & $0 \%$ & 1603 & $0 \%$ & 1817 & $0 \%$ \\
\hline 269 & $0 \%$ & 630 & $0 \%$ & 1233 & $0 \%$ & 1604 & $0 \%$ & 1818 & $0 \%$ \\
\hline 270 & $0 \%$ & & & 1234 & $0 \%$ & 1605 & $0 \%$ & 1819 & $0 \%$ \\
\hline
\end{tabular}




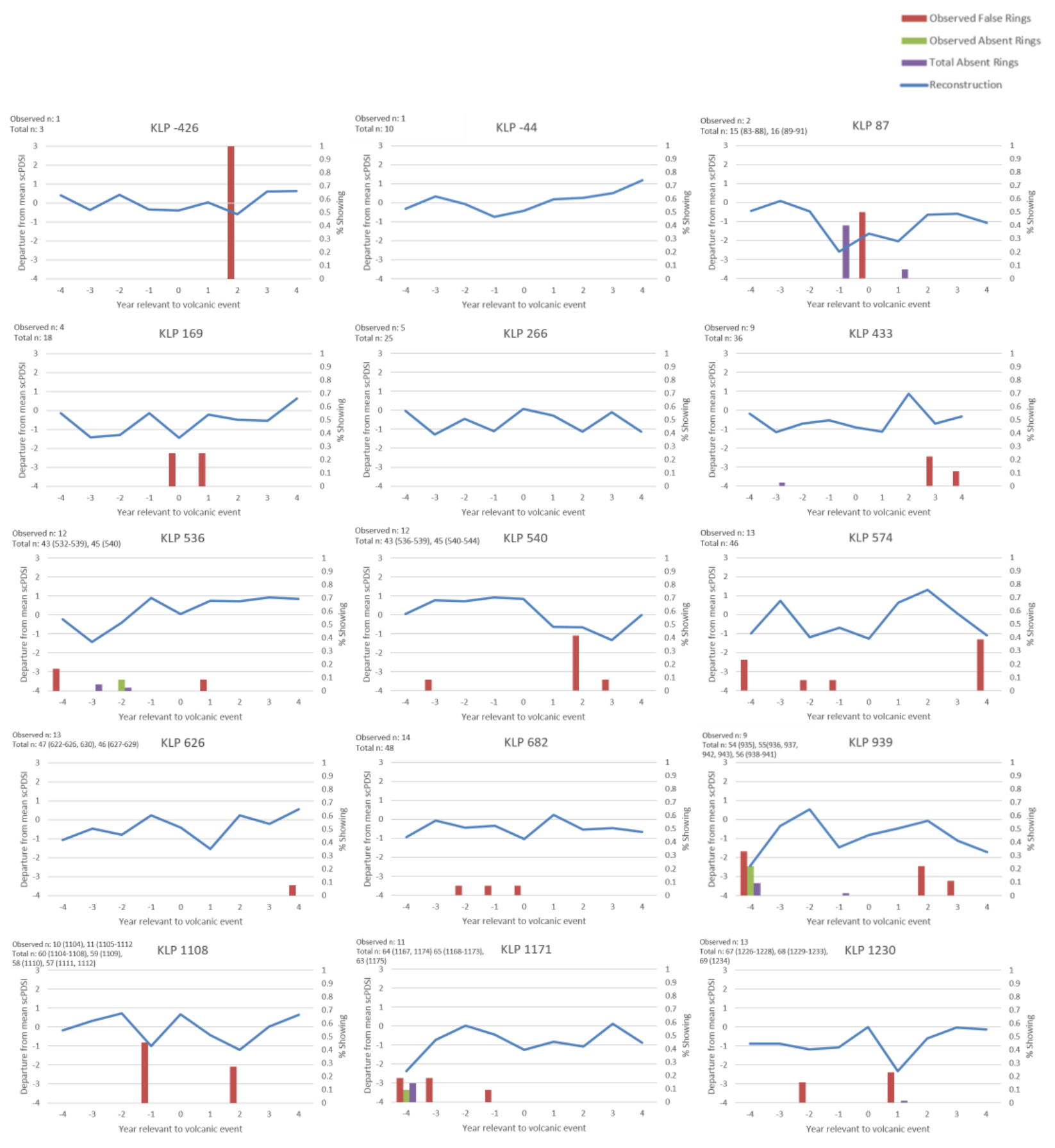




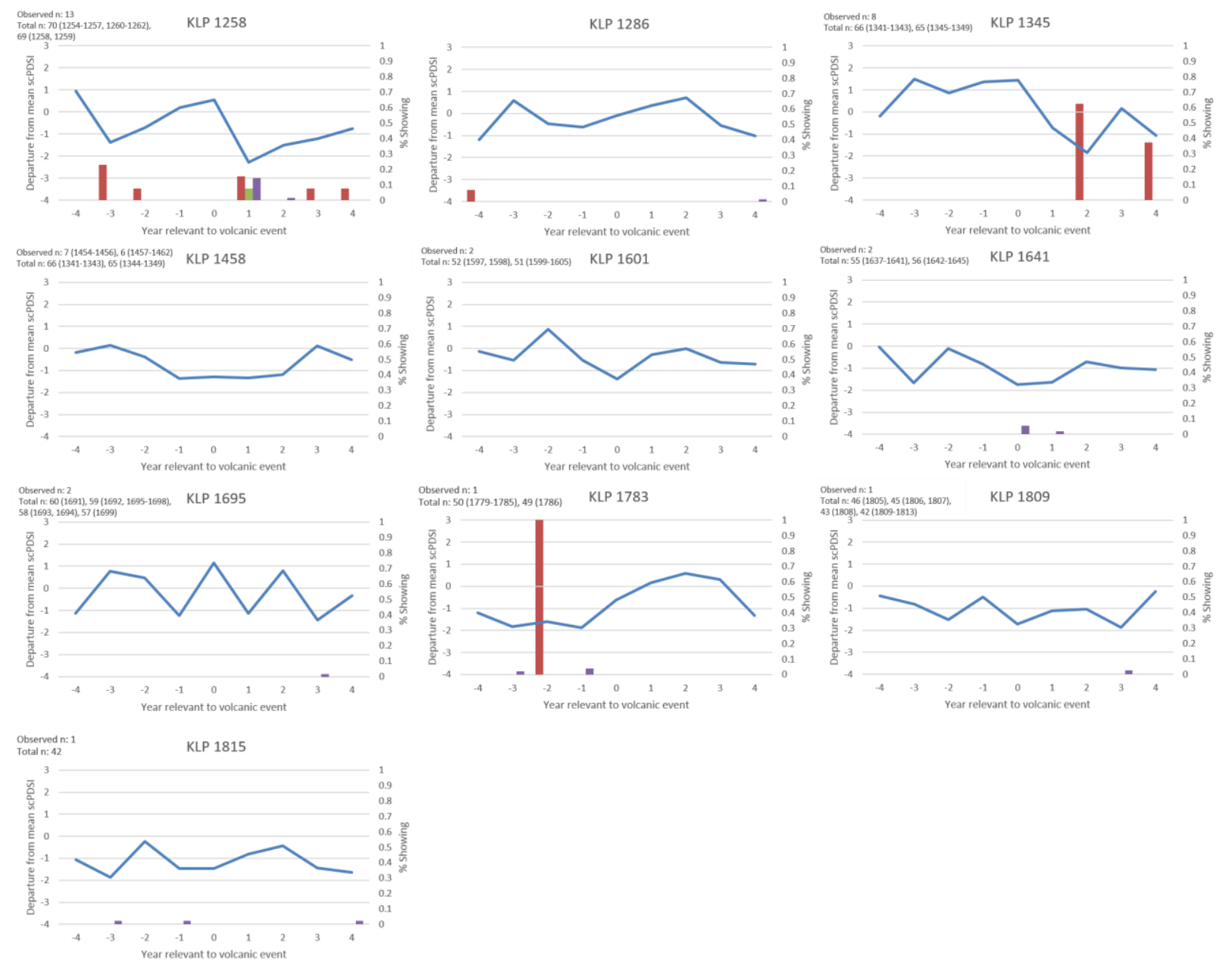

Figure 19: Plotting reconstruction values against percent observed false rings, percent observed absent rings, and percent total absent rings at Khorgo lava 

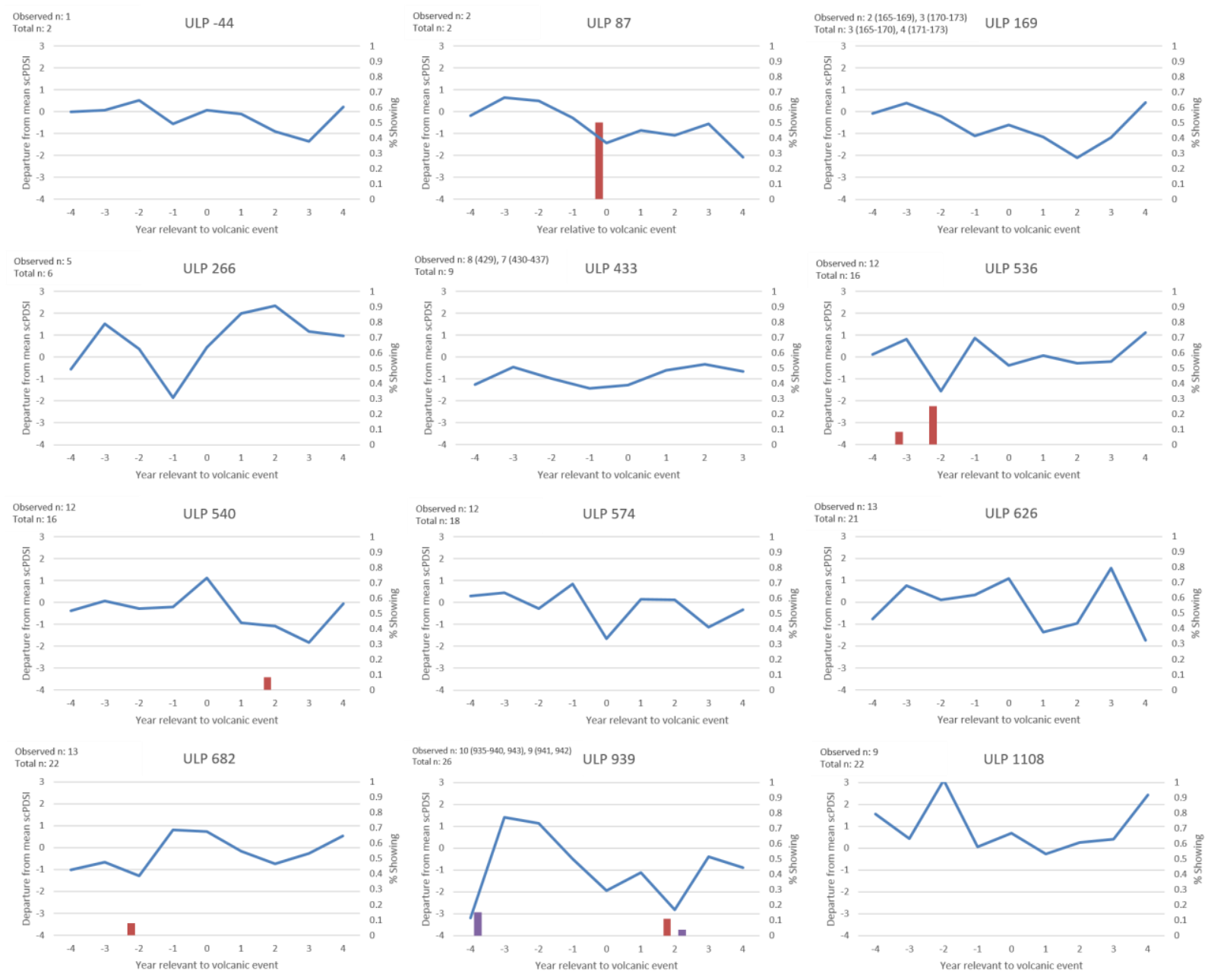

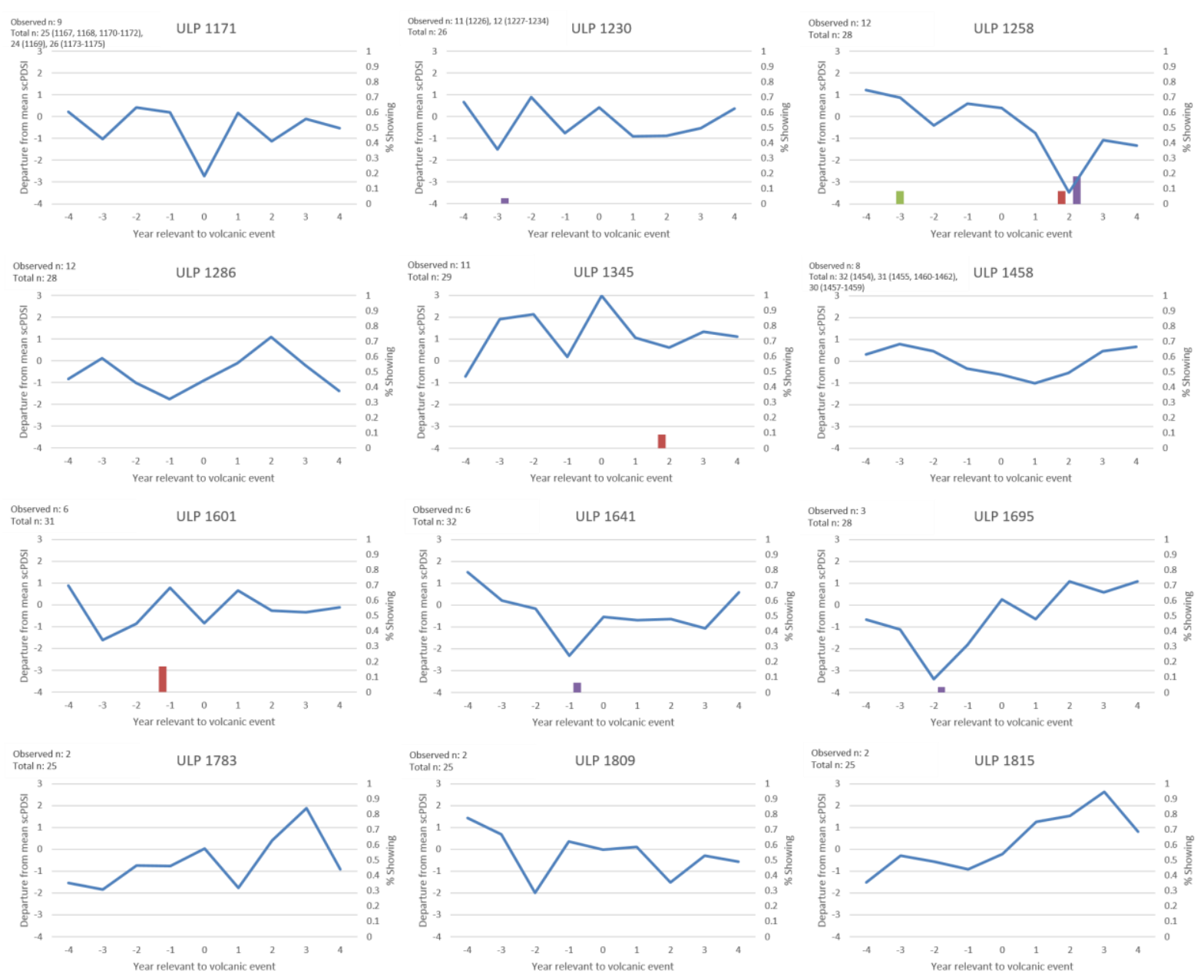

Figure 20: Plotting reconstruction values against percent observed false rings, percent observed absent rings, and percent total absent rings at Urgaat lava 
Table 17: Chi-square results at Khorgo lava (KLP) and Urgaat lava (ULP) for false rings and absent rings

chi-square test

Khorgo False Rings

\begin{tabular}{l|l}
\hline Year & p-value \\
\hline 0 & 0.098 \\
1 & 0.809 \\
2 & 0.013 \\
3 & 0.353 \\
4 & 0.429 \\
Total, 0-4 & 0.458 \\
\hline
\end{tabular}

chi-square test Urgaat False Rings

\begin{tabular}{l|l}
\hline Year & p-value \\
\hline 0 & 0.704 \\
1 & 0.218 \\
2 & 0.112 \\
3 & 0.219 \\
4 & 0.218 \\
Total, 0-4 & 0.496 \\
\hline
\end{tabular}

chi-square test

Khorgo Absent Rings

\begin{tabular}{l|l}
\hline Year & p-value \\
\hline 0 & 0.117 \\
1 & 0.090 \\
2 & 0.019 \\
3 & 0.052 \\
4 & 0.052 \\
Total, 0-4 & 0.039 \\
\hline
\end{tabular}

chi-square test

Urgaat Absent Rings

\begin{tabular}{l|l}
\hline Year & p-value \\
\hline 0 & 0.157 \\
1 & 0.157 \\
2 & 0.033 \\
3 & 0.156 \\
4 & 0.156 \\
Total, 0-4 & 0.336 \\
\hline
\end{tabular}




\section{Discussion}

The hypothesis of this study is that historical volcanic eruptions would alter key climate attributes (temperature, moisture availability, and solar irradiance) that would be recorded in tree-ring data. We found there to be no statistical significance in the influence of volcanic eruptions but tree-ring anatomy analysis suggests that we do in fact see the effect of some eruption events at Khogo lava and Urgaat lava. Composite analysis performed during the instrumental period and SEA analysis show that there is slightly lower than average growth at all three sites following volcanic eruptions but none were statistically significant from the mean. This suggests that there is in fact little change in the tree-growth at the three sites. This is evidence for little decline in temperature and moisture availability following eruptions, and thus little change in solar irradiance.

\section{Instrumental Period Composite Analysis and SEA Analysis}

We observed no statistically significant departures in instrumental climate during eruption years. The analyses using instrumental data and tree-ring chronologies reflect the uncertainties highlighted by the IPCC (2013) in that eruptions may not be as influential to climate as once believed. If looking at only the Mount Pinatubo eruption, Mongolia is wetter. Most of Mongolia is cooler after the three eruptions but by only $\sim 0.1^{\circ}-0.3^{\circ} \mathrm{C}$ of degrees. However, after the 1991 Mount Pinatubo eruption, most of Mongolia is just slightly warmer by up to $1.0^{\circ} \mathrm{C}$. The eruptions used to construct the composite analysis during the instrumental period were some of the largest during the modern times. However, on the larger time scale, none of the three eruptions are on the list of top 25 largest eruptions. Thus the eruptions may not have been large enough to influence global climate. Other global forcing such as ENSO may have the potential to mask the effects of smaller volcanic eruptions (Robock and Mao 1994).

A recent similar study was done using a Siberian larch chronology from a nearby temperaturesensitive site, OZN (Davi et al. 2015) using a different set of eruption events. Figure 21 shows the results of her temperature-sensitive site with two different sets of eruptions running SEA. The year after the eruption is significant at the $99 \%$ confidence levels for the events listed by Crowley et al. (2008) while 
the year of the eruptions was significant at the $95 \%$ confidence levels for the events listed by Gao et al. (2008). We had expected Sol Dav to display similar results as OZN since both are temperature-sensitive chronologies but they did not. This may be because: 1) Sol Dav may not be as sensitive to temperature as OZN or 2) the events used to perform SEA influenced the results more than anticipated. Sol Dav could not be used to generate a calibrated and validated reconstruction. The events under the Sigl et al. (2015) paper may be the most recent and complete list of volcanic eruptions for the past 2500 years, but there will always be some degree of uncertainty in the dating accuracy and in the proxy methods.

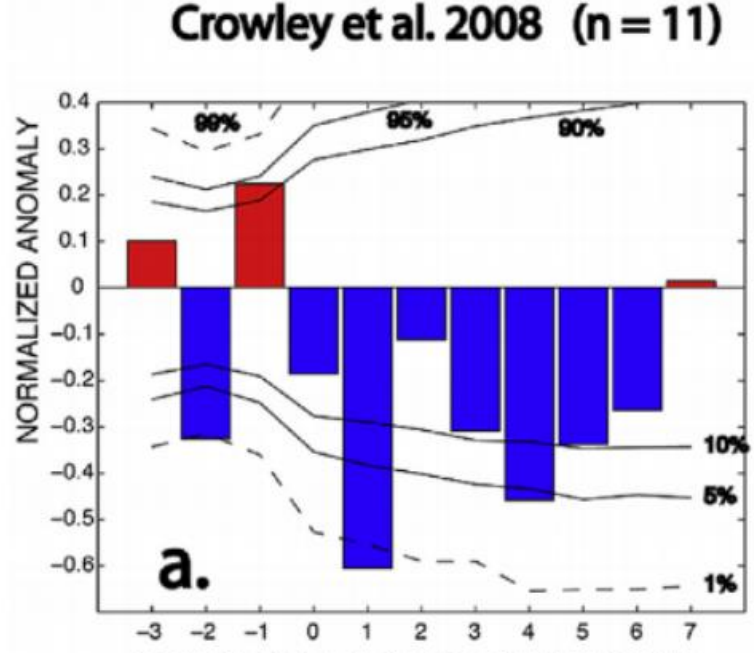

YEARS RELATIVE TO EVENT YEAR

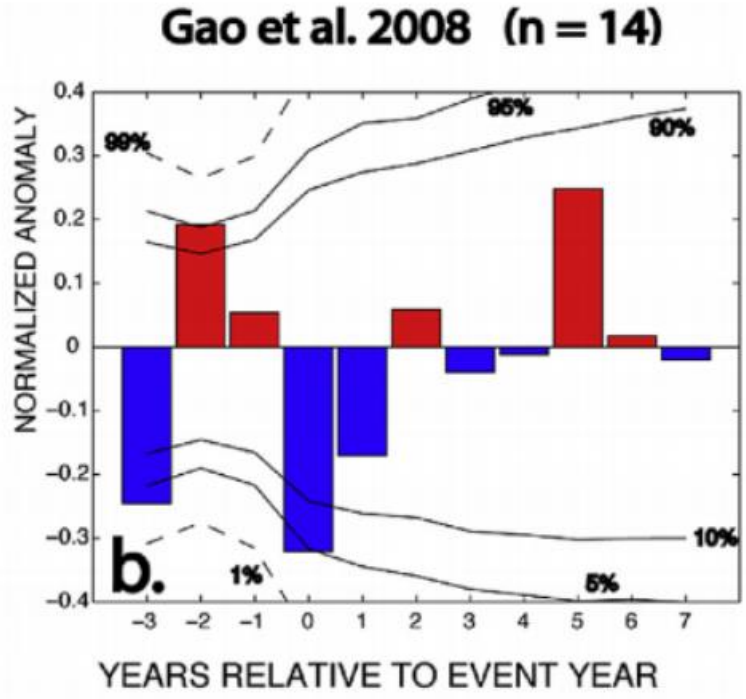

Figure 21: SEA performed using Siberian larch at OZN (Davi et al. 2015) 


\section{Wood Anatomy Discussion}

While there were no significant moisture availability changes due to volcanic eruptions found during the instrumental period composite analysis and from the statistical SEA analysis, the tree-ring anatomy hinted that we see a volcanic effect at Khorgo lava and Urgaat lava for certain eruptions.

Overall, more volcanic signals showed up at Khorgo lava than at Urgaat lava.

There were higher percentages of false and absent rings during the years analyzed and a greater number of potentially related volcanic events corresponding to the signals at Khorgo lava. However, many of these recorded false rings and absent rings occurred during the third or fourth year after the eruption event. According to previous literature, these events would be outside the realm of being influenced by a volcanic eruption (influence typically being only one to two years following the event). Thus the years that show a false ring or absent ring at Khorgo lava that may have been volcanicallyinduced are years 87, 169, 536, 540, 682, 939, 1108, 1230, 1258, 1345, and 1641 .

For those years that showed a false ring or absent rings, there was no consistency in which year the false rings or absent rings tended to show up. Eruption event 1641 produced no false rings from the observed samples however had $5.5 \%$ of the eruption year showing total absent rings, and $1.8 \%$ of the following year's total rings showing absent rings. Years 169, 536, 540, 682, 939, 1108, and 1345 only produced false rings (thus no absent rings present) during the eruption event and following two years. Eruption events 1230 and 1258 have a high amount of false rings and absent rings present and may be the eruptions that influenced Khorgo lava moisture regimes the most. Year 1259 has $14.5 \%$ missing rings in the samples that were looked at, which is out of the ordinary since it is rare for more than $5-10 \%$ of samples from trees at northern latitude sites to have a missing ring per year (St. George et al. 2013). Year two is statistically significantly different in showing false rings and absent rings according to chi-square testing. At Khorgo lava, absent rings and false rings were present between years zero to two.

At Urgaat lava however, most of the absent rings and false rings had a two-year lag after the eruption. Year two for absent rings were statistically significant according to chi-square testing. Fewer 
eruptions were evidenced at Urgaat lava. There were no observed false rings or absent rings present during the third and fourth year following an eruption. For eruption event year 87 the observed false rings fell on the eruption year. However, there was a sample depth of two at this location thus this information should not be considered as a reliable representative of the eruption event. Eruption event 540 had a false ring show up with a two-year lag. Eruption events 939 and 1258 had both false rings and absent rings present, both ring characteristics have a two-year lag following the eruption. Lastly eruption event 1345 had $9 \%$ observed false rings present with a two-year lag. Urgaat lava was relatively consistent with a decline in tree-ring growth and moisture availability by a two-year lag due to eruptions for the events that were experienced at this site location. The decline in moisture availability that showed up as false and absent rings following the 939 and 1258 eruption events hint that these two eruptions were detected at Urgaat lava and were also the strongest eruptions due to the amount of false rings and absent rings. Year 1260 has $17.9 \%$ missing rings in the samples that were looked at, which is also out of the ordinary (St. George et al. 2013). Volcanic eruption event 1258 is the only eruption that shows signs of both false rings and absent rings at Khorgo lava and Urgaat lava.

For eruption events that have sequential years showing either false rings or absent rings, it is hypothesized that there should be a decline in the ring characteristics in the following year due to the restabilization of the atmosphere from sulfate aerosols and other effects of volcanic eruptions. Tables 13 to 16 show these results. For example, it suggests that the 1258 eruption may have influenced moisture regimes greatly for 1259 while the site slowly recovers for the next three years.

The eruption events noted so far are not consistent with the global aerosol ranking calculated by Sigl et al. (2015). For the large eruptions, I observed no significant departures in climate during or after eruptions. The volcanic eruptions rankings may be based on the global aerosol forcing, but the eruptions may not have been the most influential volcanoes to impact Mongolian climate. For example, wood anatomy analysis hinted that some of the higher ranked eruptions such as 1345 (ranked 24th), 87 (ranked 23rd), 939 (ranked 20th), 1695 (ranked 19th), and 536 (ranked 18th) were found to be influential to tree 
growth at Khorgo lava and Urgaat lava but are considered as having not as great of global aerosol forcing as many other eruptions. Years 1230 and 1258 were detected at Khorgo lava, however 1230 is ranked 7th on the list while 1258 is ranked 2nd. Some large eruptions such as $-44,1458$, and 1815 (ranked 3rd, 4th, and 6th respectively) do not show up in the Khorgo lava samples. At Urgaat lava, eruption events 939 (ranked 20th) and 1258 show up in the samples. Very few of the largest eruptions show up. A couple ideas are suggested to influence the magnitude of the eruptions experienced at Khorgo lava and Urgaat lava including the timing of the eruptions (was it before or after growing season?) and the location of eruptions taking in account of global wind patterns. It is also risky to attribute these tree-ring characteristics to a decline in moisture availability. There is a possibility that it could be temperature causing them.

\section{Timing of Eruptions}

The timing of volcanic events could influence when the climatic effects due to eruptions are experienced at each location. It is hypothesized that if eruptions happened before the growing season (for Khorgo lava and Urgaat lava growing season is June, July, August, and September) then the effects may be experienced that year or later. However, if the eruptions happened in the latter half of the year or towards the end of the growing season, then the effects may be experienced the following year or later. A limitation to this study however would be the lack of knowledge on when the eruptions occurred. For more recent eruptions there may be historical evidence of when they occurred. However, it may be possible to date some eruptions from the dry fogs (deposited by volcanic eruptions) that appear in ice cores (Stothers 1999).

Table 3 and table 4 show the timing of the eruptions and which year the small ring was found (either the year of the eruption or the year after). The ring-widths were based on the reconstruction values. At Khorgo lava, eight out of the nine eruptions followed what we hypothesized. The year of the eruptions were small when the eruptions occurred before growing season or right at the beginning of growing season, or the year following the eruptions were small when the eruptions occurred after growing season. 
There was one eruption that is listed as occurring in December of 1808. This is considered as late enough in the season to effect the 1809 growing season. There is some uncertainty in the timing of the 1601 eruption based on various sources. It is listed as occurring in 1600 by various sources such as

Breitenmoser et al. (2012) and Fischer et al. (2007) even though Sigl et al. has it erupting in 1601. Due to this uncertainty, the 1600/1601 eruption was not considered during this analysis. At Urgaat lava, six out of the nine eruptions follow the hypothesis. The lower probability at Urgaat lava may be due to the twoyear lag that we experience with false rings and absent rings and this analysis only considered the year of the eruption and the year after. Potential reasoning for the two-year lag include a biological response time in trees and time it takes for the atmosphere to transport sulfate aerosols.

The timing of eruptions influences when the eruptions are possibly experienced at each location. There was an almost immediate response at Khorgo lava and Urgaat lava from eruptions. This also hints that aerosols from eruptions can travel through the atmosphere at a quick pace where it would influence tree growth within a few weeks to months. There is consistent data showing that if the eruption happened before growing season or at the beginning of growing season, then it will more likely influence tree growth the same year (Tables 3-4). If it occurred at the end of growing season or towards the end of the

year, then it influenced the following year's growth. Although this might explain for why some eruptions are experienced the year of the eruption while others the year or two after, this does not explain why only certain eruptions are experienced that are not necessarily the largest.

\section{Location of Eruptions and Wind Patterns}

Figure 2 shows the locations of the known eruptions that were analyzed during this study. Only 12 total eruptions showed up at Khorgo lava and Urgaat lava during the wood anatomy analysis: 1258, $540,1230,682,1108,1641,169,536,1695,939,87$, and 1345 (ranked from largest to smallest). Of those eruptions, we only know the location to 6 of the eruptions: 1258 (Samalas, Indonesia), 540 (Ilopango, El Salvador), 682 (Pago, New Britain), 1641 (Parker, Philippines), 939 (Eldgja, Iceland), and 1345 (El Chichon, Mexico). Five out of the six of these volcanoes are tropical. Three of them are located in 
southeast Asia and two in Mexico/Central America. Samalas, Indonesia and Pago, New Britain are located south of the equator.

There does not seem to be a pattern in the location of volcanoes that have erupted and show up in our samples. There have been other eruptions in similar areas that do not show up. For example, the 1783 eruption in Laki, Iceland (ranked 8th on the list) is near the 939 eruption of Eldgja, Iceland (ranked 20th on the list), but only the 939 eruption has a strong appearance in the samples. Global atmospheric circulation patterns in the lower latitudes (Hadley and Walker Cells) help with dispersing the aerosols into the atmosphere, but there does not seem to be any pattern in the location of the volcanoes and if those aerosols may reach the two sites in Mongolia. There is evidence of eruptions from high latitudes and the tropics at Khorgo lava and Urgaat lava, along with eruptions from the western hemisphere and eastern hemisphere. Again there is uncertainty in the location of some of the eruptions and thus analysis is limited. 


\section{Conclusion}

Results of this study suggest that the volcanic eruptions analyzed in Mongolia did not yield statistically significant influences on temperature, moisture availability, and solar irradiance as seen through the tree-ring chronologies, CRU temperature, and CRU scPDSI. However, the study also called into question the process of studying volcanic eruptions using tree-rings and the climate system, showing that the atmosphere may be an intransitive cycle where the effects of volcanic eruptions may be variable and uncertain. There were no instrumental data significance and no statistical significance based on calibrations and ring-widths found at the three sites. However, an analysis of wood anatomy hinted that some eruptions were experienced at Khorgo lava and Urgaat lava.

\section{The Effects of Recent Eruptions on Climate of Central Mongolia}

The composite analysis performed in GrADS provided conflicting but statistically insignificant results when comparing three large eruptions during the instrumental period with a 54-year average in terms of CRU temperature and scPDSI.

\section{The Effects of Volcanic Eruptions on Tree Growth Over the Past 2,500 years}

SEA analysis showed statistically insignificant results for the three sites, however, wood-anatomy analysis suggested that we do see the effects of certain volcanic eruptions on tree growth. SEA showed insignificant results for Khorgo lava, Urgaat lava, and Sol Dav for the 25 eruptions that span the past 2,500 years when we ran it four different times. We are uncertain as to why some eruptions show up while others do not. However, for the eruptions that show up (in the wood anatomy analysis), there is a slight decline in ring-width within a zero to two-year window of the eruption and occasionally the presence of a false ring or the absence of a ring. This suggests that there were periods of low moisture availability during this time window. The most notable eruption events in the past 2,500 years at Khorgo lava and Urgaat lava are years 1258, 540, 1230, 682, 1108, 1641, 169, 536, 1695, 939, 87, and 1345. 


\section{How Eruptions Influence Climate in Central Mongolia}

Results indicate that past volcanic eruptions do not alter climate as extremely as once believed. Sol Dav had statistically insignificant SEA results indicating that there was not much temperature change following eruptions. SEA results at Khorgo lava and Urgaat lava were similar in that there was not much moisture variability following eruptions. All SEA results fell within the 95\% confidence levels. However, we do see evidence of certain volcanic eruptions in the wood anatomy at Khorgo lava and Urgaat lava through the presence of narrower rings, false rings, and absent rings. This suggests that volcanic eruptions have some influence on moisture regimes. More specifically, a decline in moisture availability following certain eruptions. It is risky to attribute all of what we see during those time periods to volcanic eruptions as there may be other global forcing or micro-site forcing that was not focused on for this research (Robock and Mao 1995).

\section{Future Research}

There are some improvements that can be made for future research. A thorough analysis on the timing of eruptions based on proxies and historical records would help clean up the analysis. It would help with statistical analysis, such as SEA, if the timing of the eruptions were accurate and it would also help with identifying a pattern of when eruptions show up at each location if there were a more extended list of precise dating to the month of the eruption. Identifying the location of eruptions may be beneficial to locating this pattern as well, but proved to be difficult due to how quickly and vastly volcanic aerosols can travel. Again, more in-depth research using historical documents may be helpful. Improving on the uncertainties with using proxy records would also benefit future research. Ring width may not be the most appropriate parameter to study the abruptness or severity of eruptions at the interannual scale (D'Arrigo et al. 2009, Anchukaitis et al. 2012). An alternative, and potentially stronger parameter for temperaturesensitive trees using tree-rings is the maximum latewood density (MXD) (D’Arrigo et al. 2013). MXD can show a clear response to volcanically induced summer cooling without the lag or dampened aftereffects seen in ring width (Frank et al. 2007). This parameter is expensive and time consuming and thus 
not realistic for the project. Additionally, my main focus is on the low elevation, moisture-sensitive trees (Khorgo lava and Urgaat lava) where ring width may be a suitable proxy. There may be potential to perform MXD on moisture-sensitive trees to see if there is a temperature signal following eruptions. Lastly, this research can be strengthened if there were a greater sample depth for the wood anatomy analysis. For this research, 52 samples were analyzed between Khorgo lava and Urgaat lava. There are another 59 samples available at the Montane Forest Dynamics Lab that have not been analyzed, and many more samples at the Lamont-Doherty Earth Observatory lab at Columbia University. Overall, this research showed that tree-rings are an invaluable proxy to volcanic eruption and climate studies. While many studies have used ring-width parameters to study volcanic eruptions via statistical methods, treering anatomy should also be considered. 


\section{References}

Anchukaitis, K. J., B. M. Buckley, E. R. Cook, B. I. Cook, R. D. D’Arrigo, and C. M. Ammann. "Influence of Volcanic Eruptions on the Climate of the Asian Monsoon Region." Geophysical Research Letters 37, no. 22 (November 1, 2010): L22703. doi:10.1029/2010GL044843.

Anchukaitis, Kevin J., Petra Breitenmoser, Keith R. Briffa, Agata Buchwal, Ulf Büntgen, Edward R. Cook, Rosanne D. D’Arrigo, et al. “Tree Rings and Volcanic Cooling.” Nature Geoscience 5, no. 12 (December 2012): 836-37. doi:10.1038/ngeo1645.

Bradley, Raymond S., and Philip D. Jonest. “'Little Ice Age’ Summer Temperature Variations: Their Nature and Relevance to Recent Global Warming Trends.” The Holocene 3, no. 4 (December 1, 1993): 367-76. doi:10.1177/095968369300300409.

Breitenmoser, Petra, Jürg Beer, Stefan Brönnimann, David Frank, Friedhelm Steinhilber, and Heinz Wanner. "Solar and Volcanic Fingerprints in Tree-Ring Chronologies over the Past 2000 Years."

Palaeogeography, Palaeoclimatology, Palaeoecology 313-14 (January 1, 2012): 127-39. doi:10.1016/j.palaeo.2011.10.014.

Briffa, K. R., P. D. Jones, F. H. Schweingruber, and T. J. Osborn. "Influence of Volcanic Eruptions on Northern Hemisphere Summer Temperature over the Past 600 Years.” Nature 393, no. 6684 (June 4, 1998): 450-55. doi:10.1038/30943.

Cook, Edward R., and Richard L. Holmes. "Users manual for program ARSTAN." Laboratory of Tree-Ring Research, University of Arizona, Tucson, USA (1986).

D’Arrigo, Rosanne, David Frank, Gordon Jacoby, and Neil Pederson. "Spatial Response to Major Volcanic Events in or about AD 536, 934 and 1258: Frost Rings and Other Dendrochronological Evidence from Mongolia and Northern Siberia: Comment on R. B. Stothers, 'Volcanic Dry Fogs, Climate Cooling, and Plague Pandemics in Europe and the Middle East' (Climatic Change, 42, 1999)." Climatic Change 49, no. 1-2 (April 2001): 239-46. doi:10.1023/A:1010727122905. 
D’Arrigo, Rosanne, Gordon Jacoby, David Frank, Neil Pederson, Edward Cook, Brendan Buckley, Baatarbileg Nachin, R. Mijiddorj, and Chultamiin Dugarjav. “1738 Years of Mongolian Temperature Variability Inferred from a Tree-Ring Width Chronology of Siberian Pine.” Geophysical Research Letters 28, no. 3 (February 1, 2001): 543-46. doi:10.1029/2000GL011845.

D’Arrigo, Rosanne, Rob Wilson, and Alexander Tudhope. “The Impact of Volcanic Forcing on Tropical Temperatures during the Past Four Centuries.” Nature Geoscience 2, no. 1 (January 2009): 51-56. doi:10.1038/ngeo393.

D’Arrigo, Rosanne, Rob Wilson, and Kevin J. Anchukaitis. "Volcanic Cooling Signal in Tree Ring Temperature Records for the Past Millennium.” Journal of Geophysical Research: Atmospheres 118, no. 16 (August 27, 2013): 9000-9010. doi:10.1002/jgrd.50692.

Davi, N. K., R. D’Arrigo, G. C. Jacoby, E. R. Cook, K. J. Anchukaitis, B. Nachin, M. P. Rao, and C. Leland. “A Long-Term Context (931-2005 C.E.) for Rapid Warming over Central Asia.” Quaternary Science Reviews 121 (August 1, 2015): 89-97. doi:10.1016/j.quascirev.2015.05.020.

Devine, J. D., H. Sigurdsson, A. N. Davis, and S. Self. "Estimates of Sulfur and Chlorine Yield to the Atmosphere from Volcanic Eruptions and Potential Climatic Effects.” Journal of Geophysical Research: Solid Earth 89, no. B7 (July 10, 1984): 6309-25. doi:10.1029/JB089iB07p06309.

Doty, B. (1995). The grid analysis and display system. GRADS Manual, 10, 148.

Dutton, Ellsworth G., and John R. Christy. "Solar Radiative Forcing at Selected Locations and Evidence for Global Lower Tropospheric Cooling Following the Eruptions of El Chichón and Pinatubo.” Geophysical Research Letters 19, no. 23 (December 2, 1992): 2313-16. doi:10.1029/92GL02495.

Fischer, E. M., J. Luterbacher, E. Zorita, S. F. B. Tett, C. Casty, and H. Wanner. "European Climate Response to Tropical Volcanic Eruptions over the Last Half Millennium.” Geophysical Research Letters 34, no. 5 (March 1, 2007): L05707. doi:10.1029/2006GL027992. 
Frank, David, Ulf Büntgen, Reinhard Böhm, Maurizio Maugeri, and Jan Esper. "Warmer Early Instrumental Measurements versus Colder Reconstructed Temperatures: Shooting at a Moving Target.” Quaternary Science Reviews 26, no. 25-28 (December 2007): 3298-3310. doi:10.1016/j.quascirev.2007.08.002.

Gennaretti, Fabio, Dominique Arseneault, Antoine Nicault, Luc Perreault, and Yves Bégin. "Volcano-Induced Regime Shifts in Millennial Tree-Ring Chronologies from Northeastern North America.” Proceedings of the National Academy of Sciences 111, no. 28 (July 15, 2014): 10077-82. doi:10.1073/pnas.1324220111.

George, Scott St., Toby R. Ault, and Max C. A. Torbenson. "The Rarity of Absent Growth Rings in Northern Hemisphere Forests Outside the American Southwest.” Geophysical Research Letters 40, no. 14 (July 28, 2013): 3727-31. doi:10.1002/grl.50743.

Gu, Lianhong, Dennis D. Baldocchi, Steve C. Wofsy, J. William Munger, Joseph J. Michalsky, Shawn P. Urbanski, and Thomas A. Boden. "Response of a Deciduous Forest to the Mount Pinatubo Eruption: Enhanced Photosynthesis.” Science 299, no. 5615 (March 28, 2003): 2035-38. doi:10.1126/science.1078366.

Handler, Paul. "Possible Association of Stratospheric Aerosols and El Nino Type Events." Geophysical Research Letters 11, no. 11 (November 1, 1984): 1121-24. doi:10.1029/GL011i011p01121.

Hansen, James E., Wei-Chyung Wang, and Andrew A. Lacis. "Mount Agung Eruption Provides Test of a Global Climatic Perturbation.” Science 199, no. 4333 (March 10, 1978): 1065-68. doi:10.1126/science.199.4333.1065.

Holmes, Richard L. "Computer-Assisted Quality Control in Tree-Ring Dating and Measurement.” Tree-Ring Bulletin 43 (1983): 69-78.

Hyde, William T., and Thomas J. Crowley. "Probability of Future Climatically Significant Volcanic Eruptions.” Journal of Climate 13, no. 9 (May 1, 2000): 1445-50. doi:10.1175/15200442(2000)013<1445:LOFCSV>2.0.CO;2.

Johnson, Douglas A., Dennis P. Sheehy, Daniel Miller, and Daalkhaijav Damiran. "Mongolian Rangelands in Transition.” Science et Changements Planétaires / Sécheresse 17, no. 1 (September 15, 2006): 133-41. 
Jones, P.D., New, M., Parker, D.E., Martin, S. and Rigor, I.G., 1999: Surface air temperature and its variations over the last 150 years. Reviews of Geophysics 37, 173-199, doi:10.1029/1999RG900002

Keigwin, Lloyd. "The Little Ice Age and Medieval Warm Period in the Sargasso Sea - ProQuest.” Accessed January 15, 2016. http://search.proquest.com/openview/e8d9990c94e19b0f4d7191d0735ad60f/1?pqorigsite $=$ gscholar.

Kelly, P. M., and C. B. Sear. "Climatic Impact of Explosive Volcanic Eruptions.” Nature 311, no. 5988 (October 25, 1984): 740-43. doi:10.1038/311740a0.

LaMarche Jr., V., and K.K. Hirschboeck. "Frost Rings in Trees as Records of Major Volcanic Eruptions." Nature 307 (1984): 121-26.

Lamb, H. H. "Volcanic Dust in the Atmosphere; with a Chronology and Assessment of Its Meteorological Significance." Philosophical Transactions of the Royal Society of London A: Mathematical, Physical and Engineering Sciences 266, no. 1178 (July 2, 1970): 425-533. doi:10.1098/rsta.1970.0010.

Lavigne, Franck, Jean-Philippe Degeai, Jean-Christophe Komorowski, Sébastien Guillet, Vincent Robert, Pierre Lahitte, Clive Oppenheimer, et al. "Source of the Great A.D. 1257 Mystery Eruption Unveiled, Samalas Volcano, Rinjani Volcanic Complex, Indonesia." Proceedings of the National Academy of Sciences 110, no. 42 (October 15, 2013): 16742-47. doi:10.1073/pnas.1307520110.

Lough, J. M., and H. C. Fritts. “An Assessment of the Possible Effects of Volcanic Eruptions on North American Climate Using Tree-Ring Data, 1602 to 1900 A.D.” Climatic Change 10, no. 3 (July 1987): 219-39. doi:10.1007/BF00143903.

Mann, Michael E., Jose D. Fuentes, and Scott Rutherford. "Underestimation of Volcanic Cooling in Tree-RingBased Reconstructions of Hemispheric Temperatures.” Nature Geoscience 5, no. 3 (March 2012): 202-5. doi:10.1038/ngeo1394.

Mass, Clifford F., and David A. Portman. "Major Volcanic Eruptions and Climate: A Critical Evaluation.” Journal of Climate 2, no. 6 (June 1, 1989): 566-93. doi:10.1175/15200442(1989)002<0566:MVEACA>2.0.CO;2. 
Mass, Clifford, and Stephen H. Schneider. "Statistical Evidence on the Influence of Sunspots and Volcanic Dust on Long-Term Temperature Records.” Journal of the Atmospheric Sciences 34, no. 12 (December 1, 1977): 1995-2004. doi:10.1175/1520-0469(1977)034<1995:SEOTIO>2.0.CO;2.

Masson-Delmotte, V. Information from Paleoclimate Archives. In: Climate Change 2013: The Physical Science Basis. Contribution of Working Group I to the Fifth Assessment Report of the Intergovernmental Panel on Climate Change. Cambridge University Press, 2013.

McCormick, M. Patrick, Larry W. Thomason, and Charles R. Trepte. "Atmospheric Effects of the Mt Pinatubo Eruption.” Nature 373 (February 2, 1995): 399-404.

McCRACKEN, M. C., and F. M. Luther. "PRELIMINAR Y ESTIMATE OF THE RADIA TIVE AND CLIMATIC EFFECTS OF THE EL CHICHON ERUPTION.” Geofísica Internacional 23, no. 3 (December 4, 2013). http://revistas.unam.mx/index.php/geofisica/article/view/39296.

Miller, Gifford H., Áslaug Geirsdóttir, Yafang Zhong, Darren J. Larsen, Bette L. Otto-Bliesner, Marika M. Holland, David A. Bailey, et al. “Abrupt Onset of the Little Ice Age Triggered by Volcanism and Sustained by Sea-Ice/ocean Feedbacks.” Geophysical Research Letters 39, no. 2 (January 1, 2012): L02708. doi:10.1029/2011GL050168.

Minnis, P., E. F. Harrison, L. L. Stowe, G. G. Gibson, F. M. Denn, D. R. Doelling, and W. L. Smith. “Radiative Climate Forcing by the Mount Pinatubo Eruption.” Science 259, no. 5100 (March 5, 1993): 1411-15. doi:10.1126/science.259.5100.1411.

Newhall, Christopher G., and Stephen Self. “The Volcanic Explosivity Index (VEI): An Estimate of Explosive Magnitude for Historical Volcanism.” In History of Geophysics: Volume 2, edited by C. Stewart Gillmor, 143-50. American Geophysical Union, 1986.

http://onlinelibrary.wiley.com/doi/10.1029/HG002p0143/summary.

Oman, Luke, Alan Robock, Georgiy Stenchikov, Gavin A. Schmidt, and Reto Ruedy. "Climatic Response to High-Latitude Volcanic Eruptions.” Journal of Geophysical Research: Atmospheres 110, no. D13 (July 16, 2005): D13103. doi:10.1029/2004JD005487. 
Parker, M.L, and L.A. Jozsa. 1973. X-ray Scanning Machine for Tree-Ring Width and Density Analyses. Wood and Fiber 5(3): 192-197.

Pederson, Neil, Amy E. Hessl, Nachin Baatarbileg, Kevin J. Anchukaitis, and Nicola Di Cosmo. “Pluvials, Droughts, the Mongol Empire, and Modern Mongolia." Proceedings of the National Academy of Sciences 111, no. 12 (March 25, 2014): 4375-79. doi:10.1073/pnas.1318677111.

Robock, Alan, and Jianping Mao. “The Volcanic Signal in Surface Temperature Observations.” Journal of Climate 8, no. 5 (May 1, 1995): 1086-1103. doi:10.1175/1520-0442(1995)008<1086:TVSIST>2.0.CO;2.

Robock, Alan, and Melissa P. Free. "Ice Cores as an Index of Global Volcanism from 1850 to the Present." Journal of Geophysical Research: Atmospheres 100, no. D6 (June 20, 1995): 11549-67. doi:10.1029/95JD00825.

Robock, Alan. "Cooling Following Large Volcanic Eruptions Corrected for the Effect of Diffuse Radiation on Tree Rings.” Geophysical Research Letters 32, no. 6 (March 1, 2005): L06702. doi:10.1029/2004GL022116.

Robock, Alan. “Volcanic Eruptions and Climate.” Reviews of Geophysics 38, no. 2 (May 1, 2000): 191-219. doi:10.1029/1998RG000054.

Roderick, Michael L., Graham D. Farquhar, Sandra L. Berry, and Ian R. Noble. "On the Direct Effect of Clouds and Atmospheric Particles on the Productivity and Structure of Vegetation.” Oecologia 129, no. 1 (September 2001): 21-30. doi:10.1007/s004420100760.

Salzer, Matthew W., and Malcolm K. Hughes. "Bristlecone Pine Tree Rings and Volcanic Eruptions over the Last 5000 Yr.” Quaternary Research 67, no. 1 (January 2007): 57-68. doi:10.1016/j.yqres.2006.07.004.

Self, Stephen, Michael R Rampino, and James J Barbera. “The Possible Effects of Large 19th and 20th Century Volcanic Eruptions on Zonal and Hemispheric Surface Temperatures.” Journal of Volcanology and Geothermal Research, Volcanism and Climate, 11, no. 1 (August 1981): 41-60. doi:10.1016/03770273(81)90074-3. 
Sigl, M., M. Winstrup, J. R. McConnell, K. C. Welten, G. Plunkett, F. Ludlow, U. Büntgen, et al. “Timing and Climate Forcing of Volcanic Eruptions for the Past 2,500 Years.” Nature 523, no. 7562 (July 30, 2015): 543-49. doi:10.1038/nature14565.

Stokes, Marvin A. An Introduction to Tree-Ring Dating. University of Arizona Press, 1996.

Stothers, Richard B. "Climatic and Demographic Consequences of the Massive Volcanic Eruption of 1258." Climatic Change 45, no. 2 (May 2000): 361-74. doi:10.1023/A:1005523330643.

Stothers, Richard B. "Volcanic Dry Fogs, Climate Cooling, and Plague Pandemics in Europe and the Middle East." Climatic Change 42, no. 4 (August 1999): 713-23. doi:10.1023/A:1005480105370.

Taylor, Billie L., Tzvi Gal-Chen, and Stephen H. Schneider. "Volcanic Eruptions and Long-Term Temperature Records: An Empirical Search for Cause and Effect.” Quart. J. R. Met. Soc. 106 (1980): 175-99.

Thouret, Jean-Claude, Jasmine Davila, and Jean-Philippe Eissen. "Largest Explosive Eruption in Historical Times in the Andes at Huaynaputina Volcano, A.d. 1600, Southern Peru.” Geology 27, no. 5 (May 1, 1999): 435-38. doi:10.1130/0091-7613(1999)027<0435:LEEIHT>2.3.CO;2.

Toon, Owen B., and James B. Pollack. “Atmospheric Aerosols and Climate: Small Particles in the Earth's Atmosphere Interact with Visible and Infrared Light, Altering the Radiation Balance and the Climate.” American Scientist 68, no. 3 (1980): 268-78.

van der Schrier, G., J. Barichivich, K. R. Briffa, and P. D. Jones. “A scPDSI-Based Global Data Set of Dry and Wet Spells for 1901-2009.” Journal of Geophysical Research: Atmospheres 118, no. 10 (May 27, 2013): 4025-48. doi:10.1002/jgrd.50355.

Wexler, H. "On the Effects of Volcanic Dust on Insolation and Weather." Bulletin of the American Meterological Society 32 (1951): 10-15.

Zhao, J., R.P. Turco, and O.B. Toon. “A Model Simulation of Pinatubo Volcanic Aerosols in the Stratosphere.” J. Geophys. Res. 100 (1995): 7315-28. 